Inst. Indus.

Relations

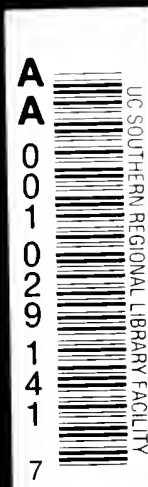




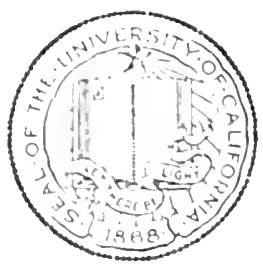

THE LIBRARY

OF

THE UNIVERSITY

OF CALIFORNIA

LOS ANGELES 
STUDIES IN HISTORY, BCONOMICS AND PUBLIC IAW

EDITED BY THE FACULTY OF POLITICAL SCIENCE OF COLUMBIA UNIVERSITY

Volume LXXIV]

[Number 3

Whole Number 176

\title{
COLLECTIVE BARGAINING IN THE LITHOGRAPHIC INDUSTRY
}

\author{
$\mathrm{BY}$ \\ H. E. HOAGLAND, Prr.D. \\ Instructor in Economics, University of Illinois
}

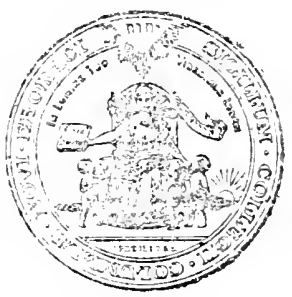

Aicw Work

COLUMBIA UNIVERSITY

LONGMANS, GREEN \& CO., AGENTS

London: P. S. KING \& SON, LTD.

I 9 I 7 
COPYright, 1917

EY

H. E. HOAGLAND 


\section{PREFACE}

Although the motion-picture poster, the label on canned foods, the office calendar, the illustrated post-card, and the numerous other products of lithography are not new to the readers of this monograph, it is improbable that many of such readers should be familiar with the process by which these articles of common use are made. Much less to be expected is an intimate knowledge of the labor problems of the industry. This study attempts to trace the history of collective bargaining in the lithographic industry. It is the hope of the writer that the facts themselves, as herein related, will interest the student of labor problems; but it is also his hope that in chronicling these facts, he may make some contribution to a better understanding of the principles of wage bargaining.

To be sure, the entire lithographic industry of the United States employs a smaller number of men than does a single corporation in the steel industry, for example. For this reason, it may be objected that the lithographic industry has labor problems peculiar to itself. This is admitted. Every industry has labor problems peculiar to itself. Yet there are common to them all the basic principles of wage bargaining. It is only by knowing intimately the methods used by employers and employees in many industries that we can determine these general principles which form the basis of the labor contract.

As far as possible, facts are permitted to speak for themselves. At no point in the study is it the purpose of the writer to pass judgment upon the intentions of either employees or employers. Instead, an attempt is $42 \mathrm{I}]$ 
mate in every case to interpret these intentions fairly and intartially. Mlenever seneral conclusions are either stated or implied, they are meant to be tentative only, to he verified later when more than one industry can be considered at the same time.

This stuly is one of a serics of investigations of wage haramining which the writer made for the United States Commission on Industrial Relations. Mlost of the information contained lierein was collected at that time, althongh some supplementary investigation has been made since. Because of the nature of the subject, care has been taken to wuote rather fully the evidence presented. Wherever specific athority is not cited in support of the statements made, it is because such statements are based inpon the verbal testimony of interested parties in the inclustry, in which case all possible means have been taken to verify such testimony, or upon information obtained from sources, such as personal letter files, to which no specific reference can be given.

The writer takes this occasion to acknowledge his in(e)tedness to all interested parties in the lithographic industry who assisted him in the work of collecting the information upon which this study is based; and especially to the officials of unions and employers' associations, past and present, who unhesitatingly stated their positions to him. Outside of the industry, the writer is indebted to Prof. George E. Barnett for the loan of union convention proceedings from the Johns Hopkins library; to Prof. E. R. A. Seligman for suggestions concerning the form of presentation and for the final reading of the manuscript; to Dr. L. IV. Hatch for preliminary reading of the manuscript; and to Mr. S. B. Dicker and my wife, Mrs. Edna H. Hoagland, for assistance in reading proof.

H. E. Hoagland.

UNiversity of Illinois, April 2, 1917. 


\section{CONTENTS}

INTRODUCTION

Origin of lithography

Methods. . . . . . . . . . . . . . . . . 12

Trades involved . . . . . . . . . . . . . . . . . I3

Strategic position of labor. . . . . . . . . . . . . . 15

CHAPTER I

The Development of Organization

Early unions . . . . . . . . . . . . . . . . . . 17

Attempts to organize employers . . . . . . . . . . . 18

Purposes of employers' associations . . . . . . . . . . . . . . 19

Methods of early unions . . . . . . . . . . . . . . . 22

First open clash. . . . . . . . . . . . . . . 23

Arbitration tried. . . . . . . . . . . . . . . . . 25

Union victory. . . . . . . . . . . . . . . . 28

Results .................... . . 28

Division among employers. . . . . . . . . . . . . . 30

Labor policies of employers' associations. . . . . . . . . . . $3^{\mathrm{I}}$

CHAPTER II

Mutual Government Defined

Employers unite. . . . . . . . . . . . . . . . . . 37

Request joint action with unions. . . . . . . . . . . . . . . $3^{8}$

Outline of plan proposed . . . . . . . . . . . . . . . $3^{8}$

Rejected by unions. . . . . . . . . . . . . . . . . 40

Shortage of workmen. . . . . . . . . . . . . . . . 45

Apprenticeship policies. . . . . . . . . . . . . . . 4 47

Employers insist upon joint action ............ . 5 I

CHAPTER III

Mutual Government on trial

Unions coöperate for defense. . . . . . . . . . . . . . 53

Employers issue ultimatum . . . . . . . . . . . . . . . . . 55

Lockout threatened . . . . . . . . . . . . . . . 57

Negotiations begun. . . . . . . . . . . . . . . . . . . 57

$423] \quad 7$ 
Indivulual contracts ofered. . . . . . . . . . . . . ${ }_{5}^{5}$

Mediation by Xational Civic Federation. . . . . . . . . . 59

Agreement renched . . . . . . . . . . . . . . . 00

Vichry for employers. . . . . . . . . . . . . . . 6 6

Mcaning of victory. . . . . . . . . . . . . . . 6 6

CIAPTER IV

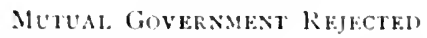

lisiensions among unions and in association. . . . . . . . . 63

New algnment of unions. . . . . . . . . . . . . . . 65

New ayreements liscussed . . . . . . . . . . . . . . . 66 66

l)emand for 48 hour week . . . . . . . . . . . . . 66

Means of obtaining it. . . . . . . . . . . . . . . . 69

Employers unite again . . . . . . . . . . . . . . . . 74

Lnions reject proposed agreements . . . . . . . . . . . . . . . 79

End of mutual government . . . . . . . . . . . . 79

CIAPTER V

Preparation for Conflict

Alliance of unions broken. . . . . . . . . . . . . . . 8 I

Peremptory demand for 48 hour week . . . . . . . . . . . . . 82

Reorganization of employers' association. . . . . . . . . . . . . . 82

Declaration of principles.... . . . . . . . . . . . . 83

Plan of organization .......... . . . . . . . 84

Centralization of control. . . . . . . . . . . . . . . 85

Power over members. . . . . . . . . . . . . . . . . . . . 87

Management of labor controversies. . . . . . . . . . . . . 88

Unions' failure to prepare for conflict . . . . . . . . . . . . . 9 9o

\section{CHAPTER VI}

OpeN Shop Established

Employers plan to declare "open shop". . . . . . . . . . . . . . 92

Await overt act by unions. . . . . . . . . . . . . . . . . . . 92

Long-term individual contracts offered . . . . . . . . . . . . 93

Strike declared . . . . . . . . . . . . . . . . . . . 97

Forced resignations from unions . . . . . . . . . . . . . . 97

Use of blacklist . . . . . . . . . . . . . . . . . . 98

Organized capital supports employers . . . . . . . . . . . . . 99

Public opinion influenced. . . . . . . . . . . . . . . . 100

Employers refuse arbitration. . . . . . . . . . . . . . 104

Punishment of members dealing with unions. . . . . . . . . I05

Loss of strike. . . . . . . . . . . . . . . . . . . 106

Meaning to unions. . . . . . . . . . . . . . . . Io6 
Maintenance of Open Shop

Strategic strength of one union. . . . . . . . . . . . . . . 107

Association essentially non-union. . . . . . . . . . . . 109

Labor policy of association . . . . . . . . . . . . . . III I

Concede 48 hour week. . . . . . . . . . . . . . . II I

Employment bureaus. . . . . . . . . . . . . . . . $\mathrm{I}_{3}$

Records of employees ................. III

Restrictions upon individual bargaining. . . . . . . . . . II4

Control of apprenticeship. . . . . . . . . . . . . . II

Vocational education. . . . . . . . . . . . . . . I19

Association a stabilizing influence .............. 120

\section{CHAPTER VIII}

\section{Conclusiun}

Effects of "open shop". . . . . . . . . . . . . . 122

Comparisons with printing industry. . . . . . . . . . . . . 122

Growing popularity of radicalism among workmen . . . . . . . I 22

Amalgamation of unions. . . . . . . . . . . . . . I23

Jurisdictional disputes . . . . . . . . . . . . . . . . 125

Standardization of working conditions. . . . . . . . . . 127

Stages in collective bargaining. . . . . . . . . . . . . I 29 



\section{INTRODUCTION}

UNLIKE many arts and crafts practiced today, lithography has preserved a fairly authentic record of its origin. The founder of the art of "writing from stone" has deprived the historian of much of the zest of research and at the same time has minimized the possibility of error by publishing the results of his discoveries. In his Vollständiges Lehrbuch der Steindruckerey, ${ }^{+}$Alois Senefelder sets forth clearly the principles of lithography.

The truth of these principles was first demonstrated in $1798^{2}$ when the first lithograph was made, largely by accident. ${ }^{3}$ It was not until several years later ${ }^{4}$ that the art was introduced into America. But by 1827 there were presses in operation in Boston, New York and

${ }^{1}$ Published in Nunich in ISI8 under the title of Vollständiges Lelhrbuch der Steindruckercy enthaltend cine richtige und dentliche Anweisung sn den aerschiedencn Manipulations-Arten dersclben in allon ihren Zavigen und Manieren, belcgt mit den nöthigen Mustcrblättern, nebst einer z'orangehonden ausfïhrlichen Geschichte dieser Kunst ion ihrem Entstchen bis auf gegenwärtige Zeit. English translation by J. W. Muller (New York, I9I I) under the title of Inocution of Lithography.

${ }^{2}$ Senefelder himself sets the date as I798. His biographers disagree in this, giving each of the years from 1796 to 1800 .

${ }^{3}$ The exact combination which was crowned with success was accidental; but Senefelder had been experimenting for several years, trying to find a means of writing from stone. See his own description of this accident in his Lehrbuch.

*The New York Lithograph, a Journal dez'oted to Lithography and Literature (New York, January, I874), vol. i, p. 3, says it was in 1824 . Others give various dates from I8I6 to I827. Cf. Joseph Pennell, Lithograplyy and Lithographers (London, I9I5), p. 217 et seq. for a discussion of the origin of lithography in America. 
l'hilulelphia. and probably in other large cities.' In Eumpe lithosraphy contumed for some time to be a means of expressing the inleas of artists: in America it soon latil the foundation for the business of selling chromos and comic pictures and became the alvertising mecium of circus managers and cigar makers. ${ }^{2}$

The art of lithography is hased npon the porosity of calcareous stones and certain metals ${ }^{3}$ and upon the chemical principle that iaty or resinous substances have an afinitv for substances of the same nature and a repugnance for water. Both lithographic ink, which is a resinous substance, and water penetrate the porous surface of the stone. The design is drawn upon the stone with lithographic ink and the remainder of the stone is moistened with water. An ink roller is then passed over the stone. The ink adheres to the design and is repelled by the moist parts of the stone. Hence the impression taken reproduces only the design.

Since the first primary division of labor, which permitted the employment of artisans skilled in separate branches of the industry, the making of lithographs has experienced few technical changes. Except for the rev. olutionary changes in the process of printing and for minor changes in the method of polishing plates and stones, the modern methods of writing from stone differ but little from those employed by the founder of the art. Indeed, the numerous texts on the subject of lithography which have appeared since Senefelder published his Lehr-

${ }^{1}$ Pennell, op. cit., p. $2 \mathrm{r} 7$.

2Ibid., p. $2 \mathrm{I} 7$.

${ }^{3}$ The scarcity of lithographic stone has caused a continual search for metal substitutes. Such substitutes are now being used for ordinary grades of work, but they are inferior to stone for fine work. $C f$. Warren C. Browne, Metal Plate Printing (New York, 1910). 
buch in 1818 have been little more than elucidations of the principles which he outlined therein.

Because the revolutionizing power of machinery, so successful in most of our industries, has been unable thus far to cope with many of the perplexing problems of lithography, the skilled workmen still retain a promi-

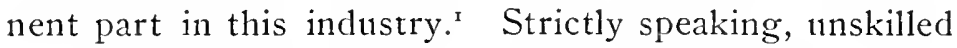
or common labor has no place in lithography. The branches of the industry, as they are organized at present and as they have been organized since the division of labor was effected, are as follows : ${ }^{2}$

The stone and plate preparers, polishers and grinders prepare the slabs of calcareous slate as they come from the quarry. This is done by rubbing together two such stones, face to face, with sand or pumice mixed with water between them. These men also grind off the ink after the stone or plate has been once used and prepare it for use again. The knowledge required to handle these stones without breaking them, to mix the proper ingredients for grinding, and to so gauge the progress of the grinding and polishing as to obtain the best results with the greatest economy of stone surface, makes this work a semi-skilled trade.

There are two methods of preparing the design which is to be lithographed. In commercial or black and white work, the design is first drawn on paper in the regular or "positive" way. Much of this work is drawn to measurement, though some of it, especially shading, is free hand.

${ }^{1}$ In 1909 the employers stated publicly that wages constitute $4 \mathrm{I}$ per cent of the cost of production in their industry. American Lithography: Its Growth, Its Development, Its Need of Tariff Protection. Published by the National Association of Employing Lithographers.

${ }^{2}$ For a description of the methods and processes employed in lithography, $c f$. Warren C. Browne, Practical Textbook of Lithography (New York, I9I2). 
Letering is drawn in the same number as other commercial desions. In eohor lithouraply and especially in poswer printing. she design is male directly upon the printins stone or plate in the reverse or "nesative" position. The lithograplic artist and designer are in fact, as well as in mame, more artists than artizans. While in commercial work direct copying and measurement are often posible. in poster worts this is seldom trie. Even in reproducing a photograph in poster form the fact that the lines must be drawn in reverse order reguires an musualy high degree of silill, while in many cases the artist has given him only the idea of a picture which he is expected to produce. The amount of skill required is indicated by the sources from which the trade is recruited. Only young men with an aptitude for drawing are taught the trade. Many apprentices have first attempted independent art work before learning lithography:

In commercial lithography, the positive design drawn on paper by the artist is reproduced on an engraving stone. The engraver cuts or scratches the image or lettering into the smooth surface of the stone in negative position for stone or direct printing rotary presses and in positive position for offset presses. A single engraving iurnishes the base for many forms.

When the engraving is finished, the transferrer pulls a transier impression from it and lays it upon a printing stone or plate in as many different places as there are required forms for printing. Color lithography of course requires no transferring, since the design is made directly upon the printing stone.

The prover then takes a proof of the stone or plate to see that all lines are clear and to make sure that the engraver has made a faithful reproduction of the original 
design. Proofs are usually taken by hand. The prover must be capable of correcting mistakes in the design.

This done, the stone or plate is turned over to the pressman. The work of the pressman is not materially different from that of the printing pressman. Considerable skill is required in mixing inks, adjusting forms, and in keeping the press in proper running order. Although the hand press is still in use in some plants for short runs, most printing is done on mechanical presses. In this one branch of the industry, machinery has revolutionized the work and greatly reduced its cost. Both mechanical stone presses and direct-printing rotary presses using plates instead of stones have been in use for some time. More recently the offset press has been introduced. The process is the same as in the stone presses except that the impression of the design to be printed is made upon a plate from which it is transferred in the process of printing to a rubber blanket and thence to paper.

The pressman is assisted by the press feeder who not only feeds the press but also assists the pressman in his work. During his period of service as a feeder, he assumes no responsibility for the work but is directed by the pressman.

The engraver, the transferrer, the prover, and the pressman are all skilled workmen. The press feeder is a semi-skilled workman.

In color lithography and in poster printing the success of the manufacturer depends, to a very large degree, upon the skill of his artists. Some commercial artists can do poster work fairly well. But except for these, there is no source of supply from which substitute workmen can be immediately obtained. Stone and plate preparers and pressmen are also indispensable. There is 
no other trade whose work is identical with that of the stone and plate preparer, but, under the direction of a competent iorman, this work can be learned in a few months. Although their work is not identical, typocraphic pressmen can learn very quickly the trade of the lithographic pressmen. In adlition, every press feeder of considerable experience is a potential pressman. With competent direction, it is an easy matter to train press feelers.

In commercial and in black and white lithography, the stone and plate preparer, the artist and designer, the engraver, the transferrer, the prover, and the pressman are all indispensable to the success of the work. Some poster artists can do commercial work satisfactorily. Stone and plate preparers, pressmen, and press feelers can be replaced in the same manner as in color lithography. The engraver and the transferrer do work which is not exactly matched in any other industry. Some other skilled workman in the industry, such as artist or transferrer, can be used to take proofs when necessary.

This brief introduction is intended to indicate the part which labor plays in the lithographic industry, in order to aid in understanding the labor policies which have dominated the labor leaders on the one hand and the spokesmen for the employers on the other. 


\section{CHAPTER I}

\section{The Development of Organization}

Previous to the Civil War there were sporadic unions in the lithographic industry in the United States. ${ }^{x}$ All of these were short-lived, however, and none of them outlived the panic of 1857 and the war which followed a short time later. With the revival of unionism a few years after the war, lithographic workmen shared in the enthusiasm for organization.

As early as I870 the employees of this industry in New York City organized a union which was local in its jurisdiction. This organization became the nucleus of the first national union in the industry, formed under the Knights of Labor in 1882. At first the lithographers had no separate charter but later a charter was granted them and an industrial union was formed which claimed jurisdiction over all skilled men in the industry, including artists, designers, engravers, provers, transferrers, and pressmen. Stone preparers were not considered skilled workmen and hence were not included. Press feeders were mere boys then and found no place in the organization.

Dissension arose within this organization and in 1890 the majority of the artists and their engravers withdrew

${ }^{1}$ For example, a strike of lithographic printers occurred in New York in May, 1853, New York Times, May 4, 1853. Several unions of lithographic workmen were in existence at this time in Philadelphia, New York, and other large cities. 
and formed the Intermational Lithographic Artists' and Engravers' Insurance and I'rotective Association of the United States and Canada. The parent organization contintued under the name of Lithographers' International Protective and Beneficial Association of the United States and Canada. It still clamed jurisdiction over the artists and engravers and, in addition, admitted stone grinders and preparers.

The first attempt of the employers to form an organization was in 188.4 . In September of that year the Lithographer and Printer sent out the following call:

To the Lithographic Tracle of the United States and Canada:

During the past four years numerous abuses have crept into the Lithographic Trade, whereby the profits of the business have been so greatly curtailed as to make it far less remunerative than it should be. As a consequence of this cutting off of profits, the standard of workmanship is, save in exceptional cases, much lower than it ought to be. Moreover, there is no unity of action among the members of the trade; in fact, there is but little acquaintance between them, though they should be bound together in close union for the furtherance of their mutual interests. Therefore,

Believing that a convention of the members of the Lithographic Trade or representatives of them, masters and workmen, will be of benefit to all of us, in the correction of abuses, comparison of methods and experiences and in a better acquaintance with each other, we invite our fellow-craftsmen to meet with us in the City of Chicago, on Nov. I7, 18 and 19, $\mathrm{I} 884$, to consider matters having any connection with or bearing on our craft and, if thought advisable, to form an International Association of Lithographers. Every firm in both countries, as well as each association of the workmen, is invited to send one or more representatives. 
Commenting upon this project, the Lithographer and Printer said :

This will be the first general meeting of lithographers ever held in America- a fact which lends added importance to the occasion. For years the trade has drifted along, without even the suggestion that its members should have any unity of purpose. Endeavoring to keep his own processes secret, after the fashion of the guilds of the Middle Ages, each one has usually been ignorant of the other's methods, except as they were taught by itinerant workmen or by peripatetic vendors of supplies. A Chinese wall of prejudice has been built between members of the craft, preventing that friendly intercourse with one another which should prevail. ${ }^{1}$

This attempt at organization failed; but the subject was kept before the employers in the industry until, on October 5, I888, the National Lithographers' Association was formed. The objects of this association, as stated in the preamble to its first constitution, were as follows :

For the purpose of furthering the interest of the Lithographic business, by collecting and dispensing such information as shall tend to stimulate the same, protect the trade from dishonest and unreliable agents and dealers, to expose misrepresentation and fraud, and to maintain profitable rates, we, a portion of the Lithographic Manufacturers of the United States, do hereby bind ourselves together under the title of "The National Lithographers' Association," and do hereby agree upon and adopt the following constitution and by-laws of our organization.

The association had a small initiation fee and nominal dues, but it had no means of disciplining its members

${ }^{1}$ Reprinted in Printers' and Lithographers' Weekly Gazette and Newspaper Reporter (New York), September 29, I884, pp. 610-11. 
who refused to olney its rules. In fact, its rules were recommendations rather than mandates, since both intermal and external canses prevented their nuiform application. For eximple, the association could not fix prices, because non-members would get the business at lower rates. It could not regulate costs, because a considerable percentage of its nembers believed the rule-of-thumb method the only one applicable to lithography and would not permit committees to attempt to standardize their costs. Hence the association merely held its annual conventions and discussed matters of interest to the trade.

The subjects which received most attention at the convention of 1894 were as follows: tariff, copyright law, hours of labor, costs, prices, and apprenticeship. ${ }^{x}$ The tariff and the copyright law were the two subjects upon which all members could agree, since all wished a prohibitive tariff on the products of their industry and all wished protective copyright laws. It was proposed that the hours of labor be made uniform as a means of standardizing costs. ${ }^{2}$ The committee on the state of trade reported against this proposition on the ground that the shops in the West were working 58 hours, while those in the East were working only 53, and that any atiempt to reduce the hours of the former would cause the western members of the association to withdraw their membership. 3 Costs and prices were discussed, but the association had no power to enforce its recommendations for the reasons given above.

\footnotetext{
'Sixth Annual Report of the National Lithagraphers' Association, passim.

"The unions were demanding shorter hours at this time also.

sixth Annual Report of the National Lithographers Association, p. $\$ 5$.
} 
The apprenticeship question has always been one of the most perplexing with which the employers have attempted to deal. At this time two forces combined to augment the difficulties involved in the training of journeymen. In the first place, the unions were demanding a more rigid limitation of the number of apprentices and the journeymen refused to teach the apprentices unless the unions were permitted to control their number. In the second place, the journeymen themselves were being speeded up in an attempt to reduce costs. The piece-work system of wage payment had been introduced to effect this result. By this time also the youth entering the trade had ceased to be apprenticed to a master workman and had become apprenticed to an industry instead. Apprentices were not indentured and boys remained in a shop only until they could better their condition elsewhere. Hence the few journeymen who were being trained were almost sure to be unfinished workmen who really learned their trade, if at all, after they secured work as journeymen.

As a result of these new forces in the industry, the training of apprentices was a costly operation to the employer and many preferred to let other shops train their journeymen. In fact, so many of the employers took this attitude that the result, combined with the union restrictions upon apprenticeship, threatened the future of the industry. Some of the leading employers, as well as some of the union leaders, recognized this danger and took steps to avert it. Joint conferences were held and a plan was outlined. This plan was endorsed at the I894 convention of the association and was as follows: That the Drexel Institute of Philadelphia be persuaded to establish a school of lithography for the training of workmen for the industry. Or, if the Drexel Institute 
combl not of would not do so, that a similar school be establishen at l'ratt lustitute, Brooklyn. No definite action, other than formal endorsement, was taken by the association. and it was not until nearly a lecade later that such a school was actually established.

The above are the suljjects with which the Lithograhers . Issociation was concerned in I894. Other subjects were discussed, stuch as ways and means of strengthening local associations of employers; but not enough interest was takcn in these other subjects to make them important. The association at this time was merely an advisory body of employers more interested in prices, tarifts, and copyrights than in labor unions.

The unions also served as open forums for the discussion of trade questions and their members at first framed recommendations rather than demands. To be sure, the union constitutions contained rules for the government of labor conditions in the industry; but these rules were not strictly enforced, and education rather than compulsion was used as the means of bringing about uniformity of trade conditions. For example, at its convention in 1895 , the president of the L. I. P. and B. A. said, in speaking of the question of hours of work:

In justice to employers who have granted the 53 hours, we should urge upon those few who still persist in working their shops longer, the injustice of this action. As the Employers' Association, of which most of those who are violating this rule are members, has frequently passed resolutions favorable to the 53 hours, I believe there should be no difficulty in gaining this point.'

In the meantime, the unions were adding to their membership and securing a greater degree of control

${ }^{1}$ Procecdings of Third Bicnnial Convention of L. I. P. and B. A., p. Io. 
over the workmen in the industry. With increased numbers came a realization of power and requests to employers gave place to demands. The unions framed their programs and presented them to employers as the conditions under which the employees proposed to work. These contracts, if they may be called such, were first local in form and as such began to operate as early as I894. This method of establishing trade rules caused some dissatisfaction among the employers, but as long as they acted as individuals they were at a disadvantage in dealing with the combined strength of their workmen.

The first open clash came in 1896 when the first national union demands resulted in combined action of the employers to resist them. In July, I 895, the New York local of the Lithographic Artists' and Engravers' Association passed the following resolutions :

I. That piece-work be declared a grievance.

2. That the General President take steps to collect moneys for an emergency fund.

3. That there be regulation and limitation of apprentices, and

4. That eighteen dollars $(\$ 18.00)$ be fixed as a minimum weekly wage. ${ }^{1}$

A special national convention met in Cleveland, December 2, I895, and agreed upon the following demands:

I. That the piece-work system be abolished.

2. All journeymen to receive not less than $\$ 18.00$ per week.

3. The following rules regulating apprentices shall be adhered to:

To every five artists, engravers and designers, one appren-

'Arbitration a Success-History of the Lithographers' Strike (New York, r8g6), p. 5. 
tice. In cases where there is only one artist, engraver and designer employed, one apprentice.

Fimployers should accept only persons who show the necessary talent, and furthermore, are to give them a trial of six months, in order to give them a chance to adopt the profession, or to prove whether they are capable of mastering the sanc: said apprentice shall be under contract for a period of not less than four (4) years. Any apprentice breaking such a contract with his employer shall forever be barred from becoming a member of this Association.

4. All overtime work shall be paid for at the rate of time and one-lialf.

5. Forty-four hours to constitute a week's work.'

Employers were then notified that these laws were "to go into effect February 24 th, I \&go." The demands were accompanied by a brief giving the reasons why they were made. The brief began as follows:

In all our deliberations on the state of the lithographic industry, and on the measures which we have decided to adopt in order to further the interests of all those actively engaged in it, the idea always paramount, and the guiding consideration above all others, was that, in deciding upon any one measure, we absolutely refrain from discriminating in favor or to the disadvantage of anybody, either employer or employee; that the interest of the employee was identical with those of the employer, and that we should endeavor to elevate the standard of our industry to the highest attainable plane.'

Then follow detailed reasons why the demands were made and must be complied with.

The employers of St. Louis, Chicago, Cleveland, Toronto, Rochester and Boston reached amicable agreements with the union, but those in Buffalo and $\mathrm{N}^{\top} \mathrm{w}$

\footnotetext{
'. Arbitration a Success, op. cit., p. 6.

2Ibid., p. 8.
} 
York ignored its demands. In the meantime, thirty-nine employers in New York City formed the Lithographers' Association of the Metropolitan District for the purpose of offering united resistance to the demands of the union. ${ }^{2}$ The trade offices ${ }^{3}$ granted the demands, thereby enabling the employers in the association to continue operations by sending work to such trade offices while fighting the union. Recognizing this possibility, the union refused to do any work in New York City until all employers had granted its demands. The employers of Buffalo followed the lead of the New York employers, and the Buffalo union acted in accord with the New York union.

At a mass meeting held February 21, 1896, a strike was called against all shops in New York City, to begin February 24. On February 25, the Metropolitan Association asked for a conference with the union. This request was refused, because it granted none of the demands of the union, and the strike began. The employers attempted to secure strike breakers but were unsuccessful. On March 17 , the L. I. P. and B. A. offered to mediate the strike. This offer was accepted by the employers but was rejected by the union. The L. I. P. and B. A. continued its efforts and on March 25 the union and the association signed an agreement to arbitrate all differences between them. The arbitration board was to consist of three members of the union, to be appointed by its president, and three members of the association, to be appointed by its president. This board was empowered to take evidence and render a decision within thirty days after its appointment.

'Arbitration a Success, op. cit., p. II.

${ }^{2}$ Ibid., p. I3.

${ }^{3}$ The trade office sub-contracts work from the manufacturer who obtains it originally. Usually the trade office or trade shop is a one-trade shop doing only printing or designing, etc. 
The anteenent provided that the decision of this joint board shomld be timal and binding mon both the mion and the employers. Anticipating a probable failure of the board to clfect a settlenent of the differences, the parties agreed that in such case this joint board should select an umpire who should be neither an employing lithographer nor a member of the union. To this umpire both partics were to submit all evidence and papers at the disposal of the joint board. I is decision was to have the same force and effect as a decision of the board.

To this arbitration board, consisting of three employers and three employees, the questions in dispute were submitted. Sessions were held from March 31 to April 9, during which time the rate for overtime and the ratio of apprentices were mutually agreed to. ${ }^{x}$ No agreement was reached in regard to hours, piece-work, and minimum wage. The union offered to accept the employers' proposal concerning hours of work, provided the latter would agree to the minimum wage and the abolition of piece-work. This proposal was rejected. Since the board could not agree upon these issues, Bishop

${ }^{1}$ In regard to the limitation of apprentices, however, the union obviously misunderstood the employers' proposal, as the following testimony shows:

Chairman (an employer): I have a proposition to submit to you on that, that where there are below five journcymen, there be one apprentice; there are to be two for five, three for ten, four for fifteen, five for twenty, six for twenty-five, seven for thirty, and so on in the same proportion.

Mr. (an employee): That is practically one for five, as I understand it.

Mr. (an employer): Exactly, one for five. Arbitration a Success, op. cit., p. Ioz.

The proposal was accepted by the union with the understanding voiced by its representative and accepted by the employers' representative, though the motion read differently. 
H. C. Potter was selected as umpire or arbitrator, under the terms of the agreement. After one session with the board, Bishop Potter asked that each side present a brief covering the points in dispute and requested that he be permitted to seek the advice of other disinterested parties before submitting his decision. This request was granted and Dr. Felix Adler and Mr. Oscar Cole acted as advisers to Bishop Potter.

In submitting his decision Bishop Potter agreed with the employers that the demand for a forty-four hour week was "unreasonable" and that the former week of fortyseven and a half hours should continue. ${ }^{x}$ On the other two points he agreed with the union and decided in favor of the abolition of piece-work and the establishment of a minimum wage. ${ }^{2}$

${ }^{1}$ Only the artists had such working hours. Other trades in the industry worked 53 to 58 hours.

${ }^{2}$ In giving his decision on these points, the Bishop said:

"The gist of the matter seems to be this: There is a tendency at the present day, among the working classes, toward increasing solidarity. There is a strong movement, among the employers of labor, to resist this tendency. The conditions implied in the wage-work system are favorable to solidarity. Hence the workmen demand it. The conditions implied in the piece-work system allow the employer to deal with the men separately, and to isolate, more or less, the interest of each from his fellows. What should be the position of the arbitrator in such a conflict? If arbitration means compromise, $I$ do not see how it is possible under these circumstances. There can be compromise as to hours of labor, as to amount of wages to be paid, as to number of apprentices to be allowed, etc. In fact, wherever the difference can be stated numerically, compromise seems clearly in order. But I do not see how there can be any compromise between opposing principles. If, nevertheless, the arbitrator or referee is required to give a decision, it seems to me he must consult his highest conscience as to which of the opposing tendencies make for the social good, and side with one or the other of the parties accordingly. In the interest of arbitration as a means of settling labor disputes, this point should be clearly stated, so that the 
The union hailed this decision as a great victory for its members. as indeed it was, since it embodied the final proposals of the workmen to the employers. The employers, on the other hand, recognizing the superior strength of their organized workmen, had hoped for a compromise. When they failed to benefit by the resort to arbitration they were none too zealous about living up) to the terms of the arbitrator's award.

This victory had an even greater significance for unionism than the securing of the immediate lemands. It gave an impetus to organization which all but overreached itself. The press feeders had always been considered apprentices to the pressmen; but the rate at which such feeders advanced was so slow that boys beginning as feeders grew to be young men and even mature men and still acted as feeders. They asked protection from the L. I. P. and B. A. but were ignored. Instead, some members of this union refused to permit the feeders to learn to operate the presses and encouraged the granting of apprentices as such who would eventually overstep the feeders and become pressmen.

This condition brought about the organization of a third union in 1898 under the name of International Protective Association of Lithographic Apprentices and Press Feeders of the United States and Canada. Dissension among the artists caused one branch of that trade to form a fourth union in 1899 under the name of Poster Artists Association of America. The increasing

distinction between arbitration and compromise may come to be recognized.

“... I regard the abolition of piece-work in the lithographers' trade and a fixed wage... as measures in harmony with the tendencies that make for social progress, and thercfore decide in favor of the men on these points." Arbitration a Success, op. cit., pp. 163-4. 
demand for stone and plate preparers gave that trade more dignity than it had had formerly and its members formed a fifth union in 1900 known as the International Association of Lithographic Stone and Plate Preparers of the United States and Canada. Finally, a sixth union in the industry was formed by the Paper Cutters. ${ }^{x}$

Although independent of each other, all of these unions, except the Paper Cutters, were involved in jurisdictional disputes. These disputes experienced periods of truce when a combined effort to fight employers was necessary, but they prevented the employees in the industry from exercising their united strength in dealing with their employers. The L. I. P. and B. A. claimed original jurisdiction over the members of each of the other unions, except the Press Feeders, whom it ignored. On the other hand, many of the feeders could operate presses and were useful to employers when the latter had difficulty with the L. I. P. and B. A. The Artists, Engravers, and Designers claimed jurisdiction over the Poster Artists and over the engravers who remained in the L. I. P. and B. A. The Poster Artists could displace the commercial artists and did so on occasion. When the Stone and Plate Preparers organized, a few remained with the L. I. P. and B. A. and caused shop troubles to arise in consequence. Since most shops contained members of nearly all, if not all, of these six unions, the possibilities of union control were small, had the employers been closely organized.

Yet in spite of these factional fights among the workmen, they were at least organized and their unions were gaining in strength. Meantime, factions developed

${ }^{1}$ Known as Local Union, No. I19, Paper Cutters of New York and Vicinity. 
anong the cruployers and cansed a sectional split between these in the Mest and those in the last. The former handed together into an association known as the Ancrican Lithographers Association, while the latter formed the Lithograpliers Association of the Linited Siates.

The American Lithographers Association gave most aticution to prices and costs and dealt with labor questions only incidentally. The Lithographers' Association of the United States very largely abandoned its attempts to regulate prices and costs and gave more and more attention to labor questions. The reasons for this diversity of interests were as follows: first, the growing strength of unionism in the East while labor organizations developed less rapidly in the West; and second, the demonstrated failure of previous attempts to regulate prices and costs in the East where competition was much more keen than in the West. A third reason was the comparative strength of the eastern employers in methods of production which made it possible for them to undersell their western competitors. Both associations attempted to extend their membership so as to become national in jurisdiction. Although they had some common interests, their main purposes were different but not antagonistic. But each refused to be absorbed by the other.

In name at least both associations claimed to be guardians of all of the inclustrial interests of their members. For example, the certificate of incorporation ${ }^{x}$ of the Lithographers' Association of the United States declared the objects of the association to be as follows:

1 The association was incorporated under the laws of the State of New York. 
To foster the lithographic trade, to reform abuses relative thereto, to secure freedom from unjust or unlawful exactions, to diffuse accurate and reliable information as to the standing of merchants and other matters, to procure uniformity and certainty in the customs and usages of the lithographic trade and commerce, and of those having a common interest therein ; to settle differences between its members and to promote a more enlarged and friendly intercourse between lithographers ; including among such objects an extension of the field of employment of lithography, an increase in efficiency, improvement in the quality of the work, all reasonable methods for effecting economies in production and the promotion of settlements of disputes between employers and employees in proper cases by arbitration or other amicable means.

The American Lithographers' Association maintained neutrality in labor matters and left control of labor questions very largely in the hands of individual employers. By 1899 the hours in almost all shops, East and West, had been reduced to 53 . This had been supported by the National Association before the split in the organization occurred. On other matters, such as wages and apprenticeship, the unions made adjustments in their policies from time to time and submitted the change to employers as individuals. The American Lithographers' Association took no action, but it was known that there was developing a growing sentiment among its members against unionism.

The Lithographers' Association of the United States, and especially those members in New York City, very early began to deal with the unions, and, as an association, virtually gave them recognition in the settlement of disputes which arose from time to time. At times agreements between the union and the employer or employers involved in the dispute followed the settlement of the 
difierenees. These agreements covered the points in dispute and usually continued in operation for a year. The former Lithograplic Association of the Metropolitan District became the nucleus of the Lithographers' Association of the lnited States and extended its policies to the cutire association.

This association soon began to pass regulations protecting its members against what it considered to be the oppressive rules of the unions. The constitution as originally adopted did not mention the unions per se, but dealt with labor questions as follows:

\section{Article VIII}

\section{Disputes}

It shall be the aim of this Assoziation to avert and avoid as far as possible all disputes between employers and employees and all strikes and lockouts, and to encourage a full discussion of all alleged grievances between employees and any concern in which members of this Association may be interested, and to endeaver to effect settlements, if possible, in all such disputes.

\section{Article VI \\ Customs and Usages of Trade}

This Association shall have power at Association meetings to take all lawful steps and proceedings to procure uniformity and certainty and reasonableness in the customs and usages pertaining to the lithographic trade and to lay down rules covering the same.

The latter article was soon amended by providing for an apprentice board

to have charge of all matters relating to apprentices to the trade, considering the question in all its details, and recommending to the members individually, or to the Board of 
Directors such action as they may, from time to time, consider advisable or for the best interests of the trade at large.

Section 5. It shall be the duty of the Apprentice Board to divide, or apportion amongst the members of the Association such total number of apprentices in the different branches of the trade as may be determined by accepted authority. It shall be the duty of each member of the Association to accept such apportionment and to employ the number of apprentices allotted to the various branches in his establishment.

This was a direct attempt to take the control of apprentices away from the unions and give it to the employers. Because the unions were able to control the supply of available men they were able to increase individual wages merely by shifting men from shop to shop. Union officials served as business agents for their members and controlled the labor market in the lithographic industry in such a manner that employers could secure workmen only through these officials. Upon receipt of a request for men, the business agents were able to secure increases for men already employed, either by shifting them from the shop in which they were employed to the one needing help, or by threatening to do so and thus forcing an increase from the employer as the price of the privilege of retaining his men. ${ }^{x}$

This practice became so common as to be considered an abuse by the employers and steps were taken to

${ }^{1}$ Even as late as Igo4 the president of the Central Lithographic Trades Council said in an address to the L. I. P. and B. A. convention:

"We have in our organization an employment bureau, through which it is possible to control the trade. Through this employment bureau it is possible to secure advances every time a change is made, and to encourage changes from shop to shop and from city to city. It is possible by this process to gain advantage." Proceedings of L. I. P. and B. A. Convention, 1904, p. 79. 
counteract it. On June 10, 1902, the association passed a resolution prohibiting any of its members from employing at a higher rate than he was accustomed to receive, any workman who had been in the employ of another member of the association. The resolution also prohibited increasing the wages of such workman within one year after entering upon his employment. ${ }^{x}$ This rule was amended on July 30 , 1902, by adding: "Provided in any case a member shall be at liberty to pay the minimum present union wages for the work for which a man is employed."

On the same date, July 30, 1902, a further step was taken to prevent an increase of wages by the concerted action of the men in a particular shop by passing a resolution authorizing the blacklisting of such men. ${ }^{2}$

However, it should be noted that the conditions which necessitated the passage of these regulations were not

${ }^{1}$ This resolution read as follows:

"Resolved; That any employee who for any reason leaves, is discharged or laid off in any shop, shall not in the shop of another member of this Association receive within one year from such time more wages than the largest wages he was paid in his last situation, and no member of this Association shall in any manner whatsoever pay to any such employce within one year from beginning of his employment in the establishment of any member of the Association more wages than the largest wages paid to him in his last situation.

"It is incumbent on every member of this Association to inquire of the Business Manager and find out what wages were paid to the person asking employment."

"The resolution read as follows:

"Rcsolved: That in cases where the Business Manager considers that the interests of the Association require it, he is authorized, in his discretion, to notify all or any of the members of the Association that he or they must not employ, on any terms, men who are, or have been working in some particular shop; and in all cases where such discretion is exercised the Business Manager shall make a full report of the facts to the Board of Directors." 
due entirely to union infuences. It was a common practice for employers to offer higher wages in order to secure the services of the employees of their competitors whenever it was advantageous to do so. This practice extended to all grades of employees. For example, on April 22, 1903, a resolution was passed prohibiting any member of the association from negotiating for the services of any salesman or confidential clerk in the employ of another member without first conferring, through the office of the association, with such other member.

The limitations placed upon the hiring of men tended to defeat their own purposes in some instances, and on August 19, I903, amendatory resolutions were passed permitting the transfer of journeymen from one shop to another at higher wages than they had been receiving provided they were transferred in good faith to higher positions, such as foremen or superintendents. Even these amendatory resolutions recognized the proprietary interest of the employer in his workmen and required that such employer be first notified, through the office of the association, before his workmen could be taken from him.

Under the system of wage bargaining ${ }^{x}$ which obtained at this time, the employers were at a double disadvantage. By competing with each other for all workmen in the industry, the employed as well as the unemployed, they were placing a premium upon resignations and changes from shop to shop. Each change weakened the bargaining power of the employer. At the same time, six unions in the industry were using their utmost efforts, first to strengthen the bargaining power of their

${ }^{1}$ Comprehending in this term the determination of all labor conditions in the industry. 
members generally by narrowly restricting the number of men in their respective branches of the industry; and second, to gain advantage for individual members-and ultimately for all members - by permitting changes from shop to shop only upon the payment of increased wages. 


\section{CHAPTER II}

\section{Mutual Government Defined}

Previous to I902, each of the employers' associations was officered by employers, with an office assistant of one of the prominent members as secretary. This plan caused dissatisfaction among some of the members. The growing strength of the unions and the increase in their demands added to this dissatisfaction and an effort was made to place the management of the Lithographers' Association of the United States in the hands of some one man who could be entirely impartial in dealing with employers and who at the same time could offer a solution for the labor problems of the industry. With this end in view, the association elected as secretary and manager a man who had been prominent in the activities of the Franklin Club-better known as the Printers' Board of Trade. This man had no business connections with the lithographic industry. He was elected by the members of the association and was responsible to them and not to a committee or group of officers.

The growing strength of the unions demonstrated to the employers, both West and East, the need for unity of action and the new manager succeeded in effecting a working agreement between the two associations to govern labor questions. In other matters the associations retained their separate identities. Under this agreement the name of the American Lithographers' Association was changed to Lithographers' Association (West) and the Lithographers' Association of the United States became the Lithographers' 
Association ( Rast). A new group was added, to include the cmpleyers on the Pacifie Coast. The name given to this group Wat lithoraphers' Association (Pacific). In reality this aroup was a part of the Lithographers' Association ( last) but it touk a separate name to maintain harmony with the Lithographers' Association (West).

The new manager of the association dominated its labor policy for nearly four years. He introduced into the industry a plan for the settlement of labor troubles which he called " Mutual govermment." He believed all employers shuuld be members of one association and all employees should be members of another and that the two should then legislate for the entire industry. He did not believe in definitive agreements. but in agreements which would establish only the machinery for determining working conditions. This machinery, once provided for, would make the laws and enforce them.

He began his campaign for such agreements in New Fork City and in September, I902, he presented to the L. I. P. and B. A. a draft of an agreement which he proposed should govern the relations of this union to the members of the Lithographers' Association (East) whose establishments were situated in Greater New York. ${ }^{1} \mathrm{He}$ proposed that all labor conditions in the industry be determined by a joint commission of thirteen members: five members of the union and five employers, to be elected by their respective organizations; the business agents of the union and the association; and an impartial umpire selected by the other members of the commission.

This joint commission was to have power to "settle and determine all matters of mutual concern" arising between the employers in Greater New York and the union. Regu-

1 For text of this proposed agreement, see Lithographers' Bulletin, July, 1903, pp. 20-2I. 
lar meetings were to be held on the first Friday of January, April, July and October; special meetings could be called at any time by the clerk of the commission or by either business agent. At the January meeting it was proposed that the commission would agree upon the "Annual Bulletin" " to guide and govern both employers and workmen during the year, and to comprehend such particulars as rates of wages, hours of labor, payment for overtime, payment for holiday work, government of apprentices, and similar questions of joint concern."

All decisions of the commission were to be final and not subject to reconsideration for at least one year, except by the written consent of all members of the commission. The business agents had the right to attend all meetings and to be heard on all questions, but they had no vote. All questions except those involving changes in the rules of procedure, which required a three-fourths vote, were to be decided by majority vote. The constitution of the commission could be amended only by the concurrent action of the association and the union. The umpire had no vote except in case of a tie. After he had given his decision in such a case, the same question could not be reconsidered within the year.

It was planned that this commission should be a court of appeals. All grievances were to be submitted first to the business agents of the association and the union. If these two officials were unable to agree upon a settlement or if their decision was not satisfactory to the interested parties, appeal could be made to the commission at its regular session or at a special meeting called for the purpose of considering the grievance. At such meeting the commission was to have power to require the presence of witnesses and the production of papers in order to secure all evidence in the case. All parties were to be given full opportunity to 
le heard: after which the decision of the commission was to he final and hinding. Pending the final settlement of any gricuance, strikes and lockouts were to be prohibited.

Lpon receipt of this proposal, the New York local of the 1. 1. P'. and B. A. appointed a committee to examine the plan and report to the union. On October 27, I902, the Lithographers Association (East) was notified that the committee

disapproves of the proposed plan or any other of a similar character, and the report of said committee has been approved by the Association.

Among the objections to the proposed plan, we desire to say, that before entering into any such agreement as is suggestecl by your Association, it would be necessary to amend the constitution of the L. I. P. and B. A. of the United States and Canada, and also the constitution of Subordinate Association No. I, of New York, in several important parts. These amendments could not be made without very serious inconvenience to both bodies, if at all. It would also take from the General Association the right of review of the action of S. A. No. I, and would take from S. A. the right of superrision and control over matters most vitally involving its own interest. and rest in five of its members absolute power and authority, without appeal therefrom, to determine any and all questions, and deprive the Association of all power in the premises. Under this plan, in the event of a controversy arising between your Association and S. A. No. I, if the five delegates representing your Association should espouse one side of the controversy, and the delegates of S. A. No. I should espouse the other side, the final determination of the issue presented would be placed in the absolute power of one person, the umpire chosen by the commission itself.

The proposed plan is further objectionable, for the reason that it involves entirely too much red tape, and the procedure suggested for the determination of any controversy which may 
arise is entirely and unnecessarily involved and cannot avoid long and vexatious delays. We desire to say further that for a period of upwards of twenty years the Lithographers' Association of New York (the union) has had no serious or violent controversy with the employing lithographers which has not yielded readily to the fair and honest treatment which this Association and its members have invariably accorded the employers. . . .

For the foregoing reasons we must respectfully decline to accept your proposed plan, and will continue to pursue in the future the course we have pursued in the past. ${ }^{1}$

This reply is typical of the attitude of the unions toward agreements of any sort at this time. The determination, expressed in the closing sentence, to "continue to pursue in the future the same course we have pursued in the past" meant that the union recognized its superior strength and expected to continue to dictate terms to the employers.

At about the same time, the employers' association approached the Poster Artists' Association for the purpose of reaching an agreement and met with about the same treatment. At a conference between the union and the association, held October I0, I902, the following resolutions were adopted :

Resolved: It is the sense of this meeting that the two associations desire to operate in harmony and to co-operate in every way possible, recognizing each other as proper and responsible parties to represent and to act for the members of each.

Resolved: It is the sense of this meeting that the setting up of a joint body, with the power to adjust differences and to determine questions of mutual concern arising in Greater New York, would be desirable and we recommend the appointment

${ }^{1}$ Lithographers' Bulletin, July I, 1903, p. 22. This Bulletin was the official organ of the L. I. P. and B. A. at this time. 
of connuitecs for each association to confer together and devise a plan for establishing snch a joint body.

The plan proposed by the employers' association was very sinular to that offered to the L. I. P. and B. A. The agreement was to be so drawn that strikes and lockouts would he prevented and that all disputes would be referred to a juint commission for adjustment. In a letter from the secretary of the Lithographers' Association (East) to the president of the Poster Artists' Association. dated Decemher 2I, I9O2, it was proposed that

At the regular meeting of the Commission in January of each year, the special business shall be to establish what shall be known as the "Annual Bulletin," to guide and govern both employers and workmen during the year.

Meanwhile a plan was on foot to consolidate the capital of the poster printers and to form one large corporation or poster trust. This plan was enthusiastically supported by the poster artists, since it was proposed that their union should have direct representation in the management of the new corporation. In other words, it was to be a combination of both capital and one branch of labor, giving to each a share in the control of the business affairs of the industry. Hence, while the Poster Artists' Association was discussing agreements with the Lithographers' Association (East), it was deferring action in the hope of consolidating into a separate organization that group of the employers in whom its members were directly interested. Perceiving this movement, the Lithographers' Association managed to frustrate the plan and the Poster Artists' Association was notified that all labor questions affecting the poster printers must be referred to the Lithographers' Association. Thereupon the union ceased to take part in joint conferences and evaded proposals for agreements of any kind. 
Efforts at agreement were continued by the employers and on January. 9, I903, the manager of the employers' association addressed to the general president of the L. I. P. and B. A. the following request:

My dear Sir:-A special committee from our Association desires to meet yourself and the National Executive Board of your Association, with the view of discussing, informally, certain trade conditions of interest to both associations. . . . ${ }^{1}$

Such a conference was granted by the union with the understanding among its officers that no agreement would be signed. The committee met on January I 5, I9O3, and after some discussion of a case in which an employer in Buffalo had violated the union rules regarding apprenticeship, the spokesman for the employers presented the following resolution, which was adopted without opposition :

Resolved that a conference be arranged between a national committee from the Lithographers' Association of the United States and the General Executive Board of the L. I. P. and B. A. of the United States and Canada, for the purpose of formulating a national apprentice plan satisfactory to both employers and employees, this plan to be afterwards submitted to both associations for ratification. ${ }^{2}$

The union regulation of apprenticeship at this time was as follows:

\section{Constitution of the L. I. P. And B. A: ARTICLE XVI}

Section I. Apprentices shall be governed as follows: To every five journeymen or fractional part thereof,- - not in each branch of the business, but in any single branch, providing five journeymen are employed; or in smaller establishments

1 Lithographers' Bulletin, December I, I903, p. 9.

Ibid., p. I0. 
where only five journeymen are employed, branches may be combined to atmit of one apprentice, but not an apprentice in each branch.

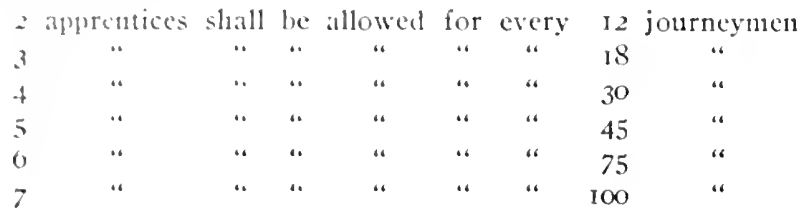

The constitution of the employers' association provided at this time for an apprentice board to have supervision over all matters relating to apprentices and to recommend to the members of the association such action as the board deemed adrisable for the best interests of the industry. ${ }^{1}$

1 As amended November 19, igoz, the article reads as follows:

\section{ARTicle VI \\ Apprentices}

"Section $\mathrm{r}$. At the annual meeting in January of each year there shall be elected a board of five (5) members, to be known as the Apprentice Board. Their term of service shall be for one year or until their successors are elected.

"Section 2. It shall be the duty of the Apprentice Board to have charge of all matters relating to apprentices to the trade, considering the question in all its details, and recommending to the members individually, or to the Board of Directors, such action as they may from time to time consider advisable, or for the best interests of the trade at large.

"Section 3. The Apprentice Board shall devise and recommend proper forms of indenture for apprentices, and shall have power to, from time to time, recommend such changes in the same as may appear to them desirable. Such forms of indenture, when approved by the Association, shall be used by all members of the Association, and no apprentice shall be engaged by any member excepting under its terms.

"Section 4. Preriously to the employment of any apprentice it shall be the duty of each member to confer with the Apprentice Board to receive its recommendation, unless by so doing, in the judgment of the member, a material injury may be done to his business. In that event, the matter must be referred to the Board of Directors, whose decision shall be final and binding upon the matter.

"Section 5. It shall be the duty of the Apprentice Board to divide or 
This board also had power to apportion apprentices among the members of the association in whatever manner it saw fit. The decisions of the board were subject to revision by the board of directors.

The conference provided for at the meeting on January I 5 was held February 2I, I903. At this conference the employers contended

that during the past few years the typographic trade has been largely increased at the expense of the lithographic trade through the existing onerous conditions, which conditions were largely caused by restrictions upon output through (a) scarcity of workmen, (b) inferior ability of apprentice graduates, and (c) uncertainty of amicable relations between employer and employee, preventing stability of contract with the producer. $^{1}$

It was shown that in $7 \mathrm{I}$ establishments which employed 447 journeymen transferrers, only 9I apprentices were found. This made possible one graduate apprentice to each 20 journeymen annually. In the same establishments 438 journeymen pressmen and but $7 \mathrm{I}$ apprentices were employed; making possible only one graduate apprentice to 25 journeymen each year. ${ }^{2}$ Statistics collected by the union showed that in the entire industry the ratio was approximately one

apportion among the members of the Association such total number of apprentices in the different branches of the trade as may be determined by accepted authority. It shall be the duty of each member of the Association to accept such apportionment and to employ the number of apprentices allotted to the various branches of his establishment.

"Section 6. Should there at any time arise a difference between any member of the Association and the Apprentice Board concerning the policy to be pursued, or regarding a decision of the Board, the matter shall be referred to the Board of Directors for settlement. All actions or decisions of the Apprentice Board shall be subject to revision by the Board of Directors."

${ }^{1}$ Lithographers' Bulletin, December I, 1903, p. ro. $\quad$ 'Ibid., p. Iо. 
to 2.3 for transferrers and one to 25 for pressmen. ${ }^{1}$ The cmployers' claims were further supported by the following statement of the amount of overtime worked in 6f shops during loor and 1902. These statistics were collected by the unions from representative shops." Overtime is calculited on a regular work-week basis of 53 or more hours. In 1901 the pressmen worked $75.4 \$_{3}$ hours overtime and the transferrers and provers worked 79,970 hours overtime: in 1902 the amounts were $S_{1,0}, 5$ and 86,468 respectively. ${ }^{3}$ This meant that pressmen, transferrers and provers in these shops averaged approximately 200 hours per year overtime for which they received wages at the rate of time and a half. Fifty-three of the 64 shops reporting stated that they had difficulty in securing a sufficient supply of men during busy times, while 23 had difficulty during dull times even. Forty-nine gave as the reason for such difficulty the apprenticeship regulations of the union. ${ }^{4}$

In spite of this demonstrated shortage of journeymen, the February conference accomplished no definite results. The only concession offered by the union was the following proposal :

That all grievances which may arise be placed before a joint commission to be elected by the two respective bodies as such grievance arises; the decision of said joint commission shall not be final or binding on either party unless ratified by both associations. In the event of the failure to agree on the part of the two associations, the question at issue shall be submitted to arbitration, provided that both associations agree to do so, and the results of such decision to be final and binding to both associations.

${ }^{1}$ Proceedings Eighth Regular Coniention L. I. P. and B. A. (in ms.) p. $48 \mathrm{~s} / 2$.

${ }^{3}$ Ibid., p. $50 \mathrm{~T} / 2$.

${ }^{3}$ Ibid., p. 50 $1 / 2$.

'Ibid., p. 50 $1 / 2$. 
This was refused by the employers as meaningless and as not being aimed at the prevention of strikes. The union members then turned a deaf ear to their employers. Instead of relaxing their apprenticeship regulations, they continued their former policy and renewed their efforts to unionize shops heretofore non-union. Considerable correspondence was exchanged, and in a letter of April 3, 1903, the employers asked for another conference, stating that:

This is outside our negotiations, which are at present incomplete, regarding the apprentice question. The conference we now ask for will probably lay the foundation for combining any agreement we may arrive at on the apprentice question with other questions of national importance. ${ }^{1}$

This letter was ignored entirely by the union. Several others followed and finally a two days' conference was arranged, to begin May 5, Igo3. The following recommendations and resolutions were passed unanimously at this conference:

\section{RATIO OF APPRENTICES \\ Transfer Department}

Establishments employing not less than 3 journeymen, I apprentice.

(6)

6

" $"$ "

“

" "

a 6 "

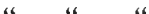

60

" " 18

" " " 27
6

(c

a

“
2 apprentices.

One additional apprentice to each 6 additional journeymen above 30 .

The ratio of apprentices for provers to be the same as for transferrers.

\section{Printing Department}

Establishments employing 2 and not less than 7 journeymen, I apprentice.

"

One additional apprentice to each 6 additional journeymen.

${ }^{1}$ Lithographers' Bulletin, December I, I903, p. I2. 


\section{Joint Apprentice Boards}

local joint apprentice boards, to be composed "of an equal munber of employers doing business in the city in which the hourl hats jurisdiction and the resident members of the subordinate association of the L. I. I'. and B. A. having jurisdiction in that city," were recommented. These boards were to have " charge of all matters relating to the employment of apprentices within their jurisdiction"; and "to insist that each establishment within its jurisdiction shall at all times cmploy the full number of indentured apprentices."

\section{Term of Apprenticeship}

I'rovers, transferrers and pressmen to be apprenticed for four years or until twenty-one years of age.

\section{Minimum Heckly Payment of Apprentices}

\begin{tabular}{|c|c|c|c|c|}
\hline & & Prowers & Transferrers & Pressmen \\
\hline First & 6 months & $\ldots \ldots \$ 5.00$ & $\$ 5.00$ & $\$ 12.00$ \\
\hline 2nd & . & $\ldots \ldots 6.00$ & 6.00 & I 3.00 \\
\hline $3 \mathrm{rd}$ & “. & $\cdots \cdots \quad 7.00$ & 7.00 & 14.00 \\
\hline 4th & ." & $\ldots \ldots 8.00$ & 8.00 & 14.00 \\
\hline 5 Ih & .* & $\ldots \ldots 9.00$ & 9.00 & 15.00 \\
\hline $6 \mathrm{th}$ & $\cdot$ & $\ldots \ldots 10.00$ & 10.00 & 15.00 \\
\hline th & “ & $\ldots \ldots 12.00$ & 12.00 & 17.00 \\
\hline 8th & $\cdot$. & $\ldots \ldots$ I 4.00 & I 4.00 & 17.00 \\
\hline
\end{tabular}

The employers contended that because of foreign competition, competition by processes other than lithography, and the existing scarcity of men on a 53 hour basis, it would be impossible to reduce the hours immediately. No conclusion was reached by the conference concerning this matter.

\section{Overtime}

Fifty-three hours to constitute a week's work and overtime to be compensated at time and a half. Sundays and national or state holidays to be paid at double time. 


\section{Prevention of Wage Increases}

On June I8, 1902, the Lithographers' Association had passed a law preventing a member from paying more to a new employee than he had received in his previous position. The employers explained that the object of this law was, "first, to prevent employers from taking unfair advantage of each other; second, to prevent manipulation of the help by the representatives of the employees." The employers assented to the following resolutions:

Resolved, It is the sense of this conference that the rule should be modified so that the right of employees to earn better wages should not be curtailed.

Resolved, That the Lithographers' Association (East and West) will carry out the foregoing resolutions, provided the union will stop all manipulation of the help.

\section{Preferential Shop}

It was voted that "preference in employment shall be given to members of the L. I. P. and B. A., and preference shall be given to members of the Lithographers' Association (East and West) in the employment of help."

\section{Blacklist}

It was agreed that " no blacklisting or discrimination of members be countenanced by either association or their individual members because of any association work done by any member."

\section{Arbitration}

Arbitration of disputes in order to prevent strikes and lockouts was discussed, but because of the union opposition to the principle of the proposal no definite plan was formulated. ${ }^{1}$

It was agreed by all the conferees to submit the above resolutions to the two associations and to recommend their

1 Lithographers Bulletin, December 1, I903, pp. I3-I4. 
adchetion. The employers athpted them, after modifying twe chunes concerning apprenticeship: one to raise the ratio in very small sheps, and the wher to leave to local apprentice bareh the determination of wage rates for apprentices. The unsion rejected the resolutions. Correspondence continned throughout the year and periodic joint conferences were held to settle specific disputed guestions which resulted in strikes.

While negotiations were still in progress with the national uniun, the New lork local presented independent demands to their employers for an increase in the minimum scale to transferrers from \$20.00 to \$25.00 per week and for nther minor concessions. Thereupon the New York members of the Lithngraphers' Association (East) turned their attention to this local and, on October 9, 1903, addressed to its president a long statement ${ }^{1}$ in which the principles of "nutual government" were reviewed and in which a request for a joint conference on the demands presented by the union was made.

The New lork local granted this request, contrary to the advice of the president of the national union, and, after slight modification of the plan offered by the employers. reached a settlement ${ }^{2}$ on October 30,1903 , which was afterward ratified by the local and by the New York members of the employers' association. The agreement provided for the establishment of temporary joint commissions to settle all differences arising between the two parties, such commission to be elected at the time the difference arose. It was further agreed that if such commission failed in its purpose, the differences would be submitted to arbitration and that the decision of the arbitrators would be final and bind-

${ }^{1}$ See National Lithographer, February, 1904, p. 5.

2 Ibid., p. 6. 
ing. Pending the settlement of differences, work was to continue without interruption.

After the agreement was ratified by both of the organizations, the general executive board of the L. I. P. and B. A. declared that local unions were forbidden by the national constitution to accept any form of arbitration without the consent of the national union and that consequently the agreement was void. ${ }^{1}$

Following this decision, the employers, at a meeting of their national association, agreed to insist upon arbitration of disputes and, on January 28 , I904, the national officers of the employers' association issued to the officers of all national unions and of all local unions in New York City a detailed statement $^{2}$ of grievances which was couched in friendly terms but which nevertheless carried the definite implication that the employers believed they were strongly enough organized to test the power of the unions to continue to dictate labor conditions in the lithographic industry.

Apparently the employers were beginning to learn the lesson of organization. Their insistent requests for mutual government were made in the hope that the unions would consent to give their employers a voice in the determination of the terms of the labor contract. The lack of response which these requests met showed the employers the futility of depending upon requests alone. As individuals they could expect but poor bargains from their well organized employees. $^{3}$ This truth they were beginning to perceive. Yet

\section{Lithographers' Bulletin, December I, 1903, p. 30.}

2 See National Lithographer, February, 1904, pp. 6-7.

3 The writer recognizes, of course, that laborers can never have an absolute advantage in their dealings with their employers: that whereas labor's refusal to work threatens only the profits of capital, capital's refusal to permit labor to earn wages threatens the very lives of the 
the lessun which it haught them was not well learned. It whe four years more of bickering and unsettled labor conditions to impress upon them the necessity of constant prepareduess for the protection of their interests.

workers. Hence in this monograph habor's advantage has definite meaning only as a measure of the share of the industry's income which the workers are able to exact for their services. 


\section{CHAPTER III}

\section{Mutual Government on Trial}

ThE unions were not yet ready to relinquish to their employers any of the power which they had been accustomed to exercise. Instead of accepting the principles of mutual government as defined by the employers, the unions began to make plans for defending their position as dictators of labor conditions in the industry. $U_{p}$ to this time each union had been strong enough, even in the face of jurisdictional fights, to deal with the employers without resorting to the expedient of joint action.

In the face of the growing strength of the employers' association the unions prepared to present a united opposition to the demands of the association. Indeed it appeared for a time that the unions, as well as the employers, were beginning to learn fully the lesson of organization. But this lesson, only half learned at the beginning, was soon forgotten; and by the time the mistake was realized, it was too late to correct it.

In December, 1903, representatives of the local unions in New York City met and passed the following resotions:

Resolved, That we, the representatives of the various associations, realizing that these questions are of national importance, do herewith recommend to our respective associations that a National Joint Committee be appointed, this Committee to consist of three representatives from each General Association, who shall meet to discuss the advisability of drawing up a set of rules governing affiliation. 
It is inrther recommencled that this Committee meet in the city of liuffales. no later than February ist, roo4.

In the meantime, the unions made no response to the circular letter from the employers association inviting the unions to a joint conference.

The suggestion for a joint committce was favorably received by the national unions and on February I. I904, a conference was held at Buffalo at which all unions in the industry were represented. This conference adopted, subject to the approval of the various unions, a plan for defensive and offensive alliance. The articles for defense pledged the unions to support each other in any difficulty which might arise with the employers and to refuse to sign any agreement which deprived the unions of the right to strike.

The articles of offensive alliance provided for the formation of a Central Lithographic Trades Council to consist of three representatives from each union in the industry. In this council each union was to retain its "distinct individuality, and at no time be compelled to act against what it may deem its own interests." It was agreed that after the plan was ratified no union could "take any action which shall result in a strike, without previously placing the matter before the Central Lithographic Trades Council and ascertaining what stand the parties to this agreement will take in relation to the questions at issue.'

On February 6, I904, the circular letter from the Lithographers' Association to the unioas was acknowledged by the union officials and the invitation to a joint conference was accepted. However, the unions had a secret understanding that no agreement would be entered into at such conference, pending ratification by the 
unions of the plan for the alliance framed at the Buffalo conference. The joint committee of unions and employers met on February 8, 1904. Finding that the unions had conspired among themselves to prevent the acceptance of any form of agreement, the employers' association presented the following ultimatum at this conference on February I2:

\section{ULTIMATUM}

Resolved-That the Joint Executive Committee representing the Lithographers' Association (East, West and Pacific), having heretofore received the authority from said Association so to act, agrees that it insist upon an agreement being drawn and executed, on or before March 15, 1904, between the (name of union) and the Employers' Association, establishing arbitration and eliminating the possibility of strikes and lockouts, and that, unless such an agreement is reached by the date named, the employers will proceed to deal with their employees individually and not through the Union.

This contract to be for a period of not less than one year from date of execution.

At this time there were 124 employers represented in the Lithographers' Association. On February I3 the association sent a letter to each of the employees of these members, urging favorable action upon the proposal for an agreement when the question was submitted to them by their unions. To counteract the effect of these letters, the union officials wrote equally strong letters opposing agreements. For example, one union president wrote his members as follows:

Our association, and all others in the lithographic field, are facing a crisis, whose issue will determine whether they, as organizations, are to survive or perish; whether labor is to longer establish the conditions under which it is willing to 
work: or whether these conditions are to be imposed by an arbitration tribunal or by the employer.

For more than a year the Lithographers' Association of the (nited States has tried, by fair means and foul, to establish what it terms " Mutual Government " or government by arbiration: and failing. it has issued an ultimatum, setting forth that the unions WUST enter into an arbitration agreement with it on, or before, March 15th, or " Employers will proceed to deal with employees individually, and not through the union."

To consent to "Mutual Government" would mean, as a first consideration, that we abandon our constitution; not only because arbitration and our governmental principle, "Direct 1.egislation," are opposed ; but "Mutual Government," according to its adrocates, does not recognize constitutions. In fact, it could not recognize them. since the Lithographers' Association wishes to "settle all differences betwcen employer and employee" thereby.

All our constitutional "demands"; the abolition of piecework, union shop, apprentice system, ... Saturday half holiday, and all, represent marked "differences" with the employer. He would naturally wish to see them abolished, and he could submit very "convincing" argument to his arbitration tribunal, to show why they should be abolished. His chance of winning would be about ten to one. . . .

Similar communications were sent out by the officals of the other unions, all of which emphasized the conflict of "mutual government" and "constitutions" and the failure of arbitration in the past. Especially was the decision of Bishop Potter in 1896 referred to as a striking example of a fair award, but it was claimed that the employers subsequently ignored its provisions because it favored the contentions of the union. In response to the ultimatum of the employers, the unions granted a conference of March 7. At this conference the employers 
offered a form of agreement which was rejected by the unions.

The employers then declared that they were opposed, not by their employees, but by a combination of labor leaders. It was evident that unless concessions were made, the employers had reached the point of making a test of strength with the union leaders to determine who controlled the men in the industry. A lockout was threatened. To prevent this, if possible, the National Civic Federation brought about a second conference on March 12. Preferring peace with a guarantee of existing conditions, to an open clash with their employers, the unions submitted a form of agreement which they promised to sign. ${ }^{x}$

This proposal provided for closed shop and the maintenance for one year of existing rates of wages, hours, overtime and holiday rates, apprenticeship regulations, and proportion of piece-work to time work. Disputes arising " on any question or point not specifically covered by the terms" of the proposed agreement were to be submitted for settlement to a joint committee composed of an equal number of representatives of the union and of the association. In the event of a failure of a majority of this committee to agree upon the settlement of a point at issue, the question was to be arbitrated. Pending the settlement of disputes, no strike or lockout was to be declared.

The employers refused to accept this proposal, saying:

We have issued a demand upon the unions that a plain, simple arbitration agreement establishing arbitration methods and joint action and eliminating strikes and lockouts for one year would be acceptable and must be made before the $15^{\text {th }}$

${ }^{1}$ See National Lithographer, March, 1904, pp. 5-6. 
uf March. Me will go further and state that the wages and homes will mot be wamered, and that the open and closed shop "fuestion should remain ats it was for one year."

In order to make another attempt to insure peace in the industry, the cmployers submitted a comter-proposal as a substitute for their original plan. ${ }^{2}$ The two important changes were as follows: First, that local joint commissions take the place of the business agents in hearing grievances and in attempting to settle them betore referring them to the national commission; and second, that the agreement as originally signed, rather than the "Annual Bulletin," determine part of the working conditions for one year.

The Central Lithographic Trades Council rejected this proposal and the conference ended without reaching an agreement. True to the threat made by the association in its ultimatum of February 12, the employers declared a lockout against all unions on March I5. On March I6 individual contracts were mailed to each employee. ${ }^{3}$ These contracts endorsed the principle of arbitration: fixed minimum wage rates, overtime rates and hours; and declared against strikes and lockouts. The association guaranteed to protect, for a period of five years, any workman who was fined or punished for signing such a contract. The term of the contract was one year, but the association reserved the right to nullify it in case an agreement was reached with the union of which the workman was a member.

In a letter which accompanied this contract and which was signed by the employer of the workman to whom it

1 National Lithographer, Narch, Ig04, p. 6.

2 lbid., p. 6 et seq.

3 lbid., pp. 12-14. 
was sent, it was stated very directly that refusal to sign the contract and return it within a stated short period of time would be accepted by the employer as a resignation of the position held by the worknan.

At the same time more definite protection from future molestation by the union was offered to some of the best men by giving them an additional contract which read as follows :

We herewith employ you as ..... in our . . . . . department for the period of five years from above date; your work to be under the direction of the Company, and subject to rules and regulations of the Company; it being understood that 53 hours are to constitute a week's work, and that overtime and work on Sundays and holidays is to be paid for as per condition in force before March I5th, I904. Your compensation is to be ... per week, and we agree to give you permanent employment during the continuance of this agreement. $^{1}$

Anticipating this action by the employers, the unions had already amended their constitutions by adding the following clause:

No member of the (name of union) shall enter into or sign any contract or agreement with his employer, unless such contract or agreement contains a distinct provision that none of the terms thereof shall in any way interfere with his obligations as a member of the (name of union).

This was effective in preventing any defections from the union ranks and the lithographic industry was completely at a standstill. Through the efforts of the National Civic Federation, the unions and the association were

${ }_{1}^{1}$ Reprinted in Proceedings of L. I. P. and B. A. Convention, 1904, p. II2. 
brought together on $\Lambda$ pril 2 in an attempt to settle the lockout. After a week's conference, a compromise agreement was reached and accepted by both the association and the unions."

This compromise agreement guaranteed the continuance of the existing conditions relative to open and closed shop: fixed minimum rates of wages and maximum lours of work; guaranteed the maintenance of overtime and holiday rates: provided for the settlement of grievances by temporary joint commissions, or, in the event of their failure to agree upon a settlement, by arbitration; declared against strikes and lockouts: assured the unions that there would be no discrimination against union men who had taken prominent parts in the existing disputes; and guaranteed the maintenance of existing apprenticeship regulations, except in the case of the $\mathrm{L}$. I. P. and B. A., which agreed to increase its ratio at its convention in July, I904. ${ }^{2}$ The life of the agreement was fixed at one year. Both parties agreed to confer on the question of its renewal at least three months before it expired.

This brief suspension of work had cost the employees at least $\$ 250,000$ in lost wages. The employers undoubtedly lost in profits a considerable amount, probably several times this sum, since some of their trade went over permanently to the three-color printing process.

Although the actual wording of the agreement was a compromise between the terms originally demanded by

${ }^{1}$ See National Lithographer, April, I904, pp. 5-7.

'A plan for national and local joint apprenticeship boards was later agreed to by the association and the L. I. P. and B. A. to govern the apprenticeship question in the industry in so far as the L. I. P. and B. A. was concerned. See National Lithographer, February, 1905, pp. 10-11. 
the employers' association and the previous policy of union dictation of labor conditions in the industry, the unions generally and the L. I. P. and B. A. especially lost ground in the settlement. To be sure, the only immediate change in labor conditions was a plan for increasing the ratio of apprentices in some branches of the industry. Other conditions were guaranteed to remain the same during the life of the agreement.

But the unions had given up their system of direct legislation or wage bargaining by union constitution and had accepted in its place the elements of the plan of mutual government proposed by the employers' association. Even though the original plan of the employers, to leave all differences to a joint commission, was not accepted in its entirety, the idea-of first joint action, and then arbitration-was the central feature of the compromise agreement.

This was a loss only in the sense that it left the unions in a less advantageous position than they were accustomed to occupy. It did not shift the weight of advantage to the side of the employers. Instead it rather tended to establish a balance in the bargaining relations of the two parties.

Perhaps the greatest loss which the unions suffered at this time was their failure to read the meaning of this agreement as projected into the future of wage bargaining in the industry. For the first time they had encountered a strong organization of employers. The latter had won their fight for recognition. If the unions were not exactly defeated, the truce at least gave the honors of the encounter to the association. Yet the entrance of this strong defensive organization of employers into the field of wage bargaining in the lithographic industry seened not to have been considered a bad omen by the unions. They still had only half learned their lesson. 
The money loss to the employers was, in a sense, an investment which paid large dividends later. The "recognition " of the association by the unions really meant as much to the employers as the recognition of the unions by employers means today in other industries. This in itself should have been sufficient cause for elation in an industry in which union dictation of labor conditions was apparently fixed. Yet not all employers considered it so. Some, misled by the impression made upon the unions and the public by the new-found strength of their association, believed that nothing short of a complete surrender of the unions should have been accepted. Such employers, like the unions, did not yet fully realize the significance of the situation. 


\section{CHAPTER IV}

\section{Mutual Government Rejected}

FROM the beginning, the agreement operated with a fair degree of satisfaction to all parties. Neither side lost its partisanship, however, and even in the semi-judicial meetings of the joint boards each party remained loyal to its cause. In addressing the L. I. P. and B. A. convention in I904, the president of the Central Lithographic Trades Council said :

The men who are appointed to interpret the agreement . . . are in duty bound to interpret it to the utmost of their ability in favor of the side which appointed them. ${ }^{1}$

However, with the settlement of the dispute between the employers and the union in the signing of the agreement for one year, came a break in the ranks of the association and in the Central Lithographic Trades Council. The Lithographers' Association (West) was dissatisfied with the agreement because it gave too much recognition to the principle of unionism and within a few months the employers under its jurisdiction reorganized their section of the association, retaining the name, but withdrawing from affiliation with the Lithographers' Association (East).

At about the same time the L. I. P. and B. A. withdrew from the Central Lithographic Trades Council. The reasons for this action are as follows: Being larger in membership than the other unions in the council and representing

${ }^{1}$ Procecdings of L. I. P. and B. A. Convention, 1904, p. 77. 479] 
nore branches of the industry than they did, it objected to the wnit plan of representation in the proceedings of the conncil. Ly numipulation of the joint conference which had franned the agreement in 1904, the Poster Artists' Association was able to secure concessions not granted to the 1.. 1. I'. and I?. I. ${ }^{1}$ This caused dissatisfaction in the latter minion. Since the 1. J. I'. and B. A. looked upon the l'ress feeders' Union as an organization of apprentices, it (bjected to dignifying such a union by sitting in council with it and by being guided in its own actions by the votes of apprentices. linally, being the parent union, the L. I. $P$. and B. A. still clained jurisdiction over all branches of the industry and objected to any lind of affiliation with other unions, short of an amalgamation which would give its own superior numbers complete control over the entire industry. Indeed. its officers had advocated amalgamation for years and had tried to make the Central Lithographic Trades Council a real amalgamation instead of an alliance. Failing in this attempt, it had entered the alliance only because of the fear of the united efforts of the employers. With a year's peace assured, it withdrew from the alliance soon after the I $90+$ agreement was signed.

As a matter of fact, the rank and file of the L. I. P. and B. A. were opposed to the alliance at the start and had rejected the plan by a referendum vote of $8_{15}$ to 27 . Notwithstanding this rejection, the officers of the union had attended the Buffalo convention and had made their organization a part of the alliance. In explaining the action of the officers later, the president said:

What we wanted ..... was to endeavor in the coming trouble to control the kindred branches so that they would assist us. ${ }^{2}$

${ }^{1}$ See National Lithographer, April, 1904, pp. 5-7.

2 Proceedings of L. I. P. and B. A. Convention, 1904, p. I25. 
In the convention of 1904 the union amended article I., section 2 of its constitution to read as follows:

Recognizing that to obtain and enjoy that which we seek can only be accomplished by a more thorough organization, we pledge ourselves to give to all kindred branches of our trade our assistance in organizing them, to give them our moral, and if necessary, our financial support. ${ }^{1}$

But under no consideration shall the last part of this section be construed as to the formation of an alliance or affiliation. ${ }^{2}$

In December, 1904, the Poster Artists' Association took the initiative in the formation of a stronger and more permanent alliance-one which would prevent any union from withdrawing during the life of an agreement. Invitations to a conference were sent out to all unions in the industry. The L. I. P. and B. A. replied that "the laws of this Association prohibit our entering any alliance." The other unions accepted the invitation and in January, 1905, a plan for a closer alliance of these unions was formulated.

The name of Central Lithographic Trades Council was retained. It was not to be considered " a ruling body, since it has no inherent legislative and but limited executive powers, but it shall be considered more especially a recommending agency." At the same time it was expected to "conduct negotiations for agreements" " and "when properly authorized" it was expected to "assume the management of strikes and lockouts " and in general to " direct such operations as require complete unity of action."

The articles of alliance provided for the organization of local lithographic trades councils to act as the medium of

1 Proseedings of L. I. P. and B. A. Convention, 1904, p. I2I.

2 Ibid., p. 126.

${ }^{3}$ No union was permitted to enter into any agreement on its own responsibility. 
communication for the several local unions. All acts of the Central Lithographic Trades Council required the approval of each constituent mion "except when furtherance of the pretective purposes of this alliance as set forth in the Preamble of these laws, makes immediate action by the Central Lithographic Trades Council imperative."

Section 6 of the articles of alliance pledged the unions not to withdraw from the alliance during the life of any agreement with the employers, whether or not such period was longer than one year. Subject to the provisions of this section. the alliance was to continue for one year from February 1, 1905, provided it was ratified by the constituent unions. The plan was acceptable to the unions and it was ratified by them. It the expiration of the I 904 agreement, in April, I905. the alliance renewed their agreement with both the Lithographers' Association (East) ${ }^{1}$ and the Lith')graphers' Association (West).

The L. I. P. and B. A. negotiated with the Lithographers' Association (East and Pacific) for an agreement to cover the year 1905-06. The union submitted a proposed agreement which differed from the existing agreement by omitting section Io dealing with apprentices, and by amending section 2 to grant the union a 48 hour week on July I, 1905, without any reduction in wages. ${ }^{2}$

'Including Lithographers' Association (Pacific).

2 The proposed section read as follows:

"Section 2. The rate of wages to be paid to the employees, members of the L. I. P. and B. A., the Party of the Second Part, shall not be reduced, and the hours of labor which shall constitute a week's work for such employees, and the daily apportionment of such hours shall be the same as are now in force and shall so continue until the first day of July, 1905, and from and after the first day of July, 1905, the hours of labor which shall constitute a weck's work for members of the Party of the Second Part shall be forty-eight hours, but no reduction in wages shall be made on account of said change in the number of hours which shall constitute a week's work."-Proceedings of $L . I . P$. and B. A. Coniention, 1906, p. 56 . 
The union had called a convention in I904, a year earlier than the time for the regular convention, for the express purpose of taking action on the 48 hour week. Accordingly, the most important event of the convention was the passage of an amendment to its constitution which obligated its officers to insist upon incorporating the 48 hour week in the next agreement. ${ }^{1}$ No agreement, either verbal or written, which did not contain such a clause, was to be accepted by the union.

Hence the union expected that both of the agreementsthe one with the Lithographers' Association (East) and the other with the Lithographers' Association (West) -would contain a 48 hour clause in 1905 . When neither of the drafts submitted to the union for ratification contained such a clause a movement was started to reject both proposed

1 The amendment read as follows:

\section{Article XIII}

"Sec. I. Forty-eight hours shall constitute a week's work for all members of the L. I. P. and B. Association. It is the sense of this convention that it shall be the duty of the General Executive Board, who has the power to enter into a future agreement with the Employers' Association, to insist upon the insertion of a clause in our next agreement that will provide for the forty-eight hour week. The hours nominated as constituting a week's work shall in all cases be the hours within the schedule limiting the day's work. The hours may be so divided as to arrange for a lesser number on the last day of the week. but the schedule having been agreed upon, the work done in time not within the schedule, shall be considered overtime and be paid time and a half. All days designated by the National or State authorities as holidays shall be so accepted by this Association, and members who are obliged to work on such days shall receive double time pay for the hours they work, including Sundays. All overtime shall be eliminated where it is possible to do so when there are members unemployed.

"Sec. 2. Members are not allowed under any circumstances to enter into any agreement with employers, either verbal or written, whereby they are expected to work more than the number of hours provided for in Section I, without receiving extra compensation as stipulated in Section I."-Proceedings of L. I. P. and B. A. Coniention, 1904, p. I63. 
agreculents. The fear of discrimination by the Lithographcrs - Issociation (liast) in favor of the other unions prevented the suceess of this movement, but the other agreement was rejected by the L. I. I. and B. A. During 1005(x) this minin had no agreenent with the Lithographers' Association (IVest). Conditions were not different from thuse of the preceling year and employers and unions were twherant rather than either hostile or cordial in their dealings with each other. While neither the union nor the association gave official recognition to the other, as an organization, members of the association clealt with the union as such.

The break between the Lithographers' Association (West) and the Lithographers' Association (East) became more marked in 1906 than it was in 1904 and the latter organization ceased its efforts to form an alliance with the former. The Association (Vest) reverted to its former policy of waiting for the unions to act while the Association (East) maintained its adherence to the principles of mutual government and sought to continue the agreement system. Under date of December I3, I905, the secretary of the Association (East) wrote the national president of the L. I. P. and B. A. as follows:

We beg to notify you that under Section 8 of the agreement for 1905 , we are prepared to have a committee from the Association meet a similar national committee from the L. I. P. and B. A. in conference, on or about January $\mathrm{I} 2 \mathrm{th}$, 1906 , for the purpose of formulating a new agreement between the organizations for a period of one year or longer, if desired. ${ }^{1}$

This request for a conference was refused on the ground that beginning January 29, the national convention of the L. I. P. and B. A. would be held for the purpose of formu-

1 Reprinted in Proceedings of L. I. P. and B. A. Convention, 1906, p. I4I. 
lating the agreements with the employers and that the employers would be invited to attend the convention. This convention was the result of the general dissatisfaction among the union members over the committee method of formulating the 1905 agreement, although it was submitted to the members for ratification. It was planned also to push through the 48 hour week which had failed in 1905 and it was expected that the union would have an advantage over the employers by meeting the latter in the manner provided by the union. The convention was called by a referendum vote of the national union and it was expressly understood that the convention, and not the executive board or a committee of any sort, must formulate the agreement if there was to be one for 1906 .

The Lithographers' Association (East) refused to meet the convention of the L. I. P. and B. A. for the following reasons :

In the first place it is the opinion of the Employers' Association that New York City, being the centre of the lithographic industry of the United States, should be the locality in which all such national conferences should be held, and it is the place where all such conferences have been held heretofore. New York City is also the fixed headquarters of the Employers' Association, and therefore the precedent that would be established by holding the conference in the city in which your general convention was being held would be a bad one as your general conventions are held each year in a different locality.

A further objection to holding the conference during the sitting of your general convention is that in the formulating of any agreement, the various conflicting interests involved require to be carefully weighed and adjusted and no such interest should be considered to the detriment of the others, and the accomplishment of such result requires that the committee in charge of the subject must first have power con- 
ierred upon them to draft the agreement according to the agreenuents presented and the conclusions arrived at between the committees, and second. the committec must be kept free luring the eonference from influences and criticisms such as would be mavoidable were the conference to be held in the presence of or during the sitting of the general convention of the 1.. 1. P. and 1:. A. or the Employers' Association. The lichling of the conference at the time which you suggest would really mean a conference, not betwecn the committecs, but between the committee from the Employers' Association and the cutire general cone'ution of the L. I. P. and B.A....

A mutual govermment agreement such as now exists between our organizations directly concerns the interest and welfare of each individual workman as well as each individual cmployer, and inasmuch as it ought, therefore, to receive the approbation of the individuals concerned, it should for this reason be submitted for ratification to the votes of the individuals comprising the membership of both organizations and not depend for its ratification or rejection upon the votes of delegated representatives who more or less fail to represent their constituents, according to the personality of the delegates. ${ }^{1}$

The Lithographers' Association (West) also refused to hold its conference at the time set. ${ }^{2}$ Neither of the communications stating such refusal was answered by the union. but when the convention met on January 29, the employers were notified that the union was ready to meet their committees for the purpose of formulating agreements. Again both employers' associations refused to meet the union for the reason given above, but both expressed their willingness to meet the union committee as soon as the convention adjourned.

${ }^{2}$ Reprinted in Proceedings of L. I. P. and B. A. Convention, 1906, pp. $100-102$.

2 Ibid., p. 102. 
Thereupon it was " moved that if the employers refuse to meet us as we request here we have no agreement until our next convention." " This motion was amended to the effect that the convention draft an agreement to be known as the "Buffalo Convention Agreement" to be submitted to the employers as an ultimatum with the understanding that they must "sign this or nothing." 2 The original motion was withdrawn in favor of the amendment which passed the convention by a vote of 62 to one. ${ }^{3}$

Before such action was taken, however, some of the more sober and conservative delegates at the convention made themselves heard and urged further efforts to induce the employers to reach an amicable agreement. Accordingly, the secretary of the recently organized Employing Lithographers' National League [the former secretary of the Lithographers' Association (East)] was invited to come to the convention and confer with the agreement committee of the union. Finding that some members of the union did not have a clear conception of his mutual government plan for governing the relations of employers and employees in the industry, the secretary of the employers' association defined mutual government as follows:

Mutual government consists of two parts, joint action and arbitration. The application of these things to the smallest as well as the greatest of our affairs constitutes what we term mutual government. ... .

The first part, joint action, consists of equal representation on the part of employers and the employees in the settlement or discussion of anything that affects trade conclitions, affects the interests of the other party directly or indirectly. Those things that have heretofore been settled under old conditions,

1 Proceedings of L. I. P. and B. A. Convention, 1906, p. I38.

${ }^{2}$ Ibid., p. 138.

3 Ibid., p. I40. 
by cither the employers or the men, mecting alone, enunciating an ultimate resolution and then fighting to force conditions, these things we place in the hands of an equal representation from the employers and the employees, and if they fail to anree or settle the question, then and then only shall it be placed wathitration and the result of the arbitration shall be fual and hindling. That is mutual goverument.'

In his oljections to the plan for mutual government as so defined, the spoliesman for the union committee, a former president of the union. said:

It has been in the past the ideal object of trade organizations when they select men to frame their laws, their laws when dated to take effect must be enforced, no way of arbitrating. This is the only way. . . I have been an officer of this association and I have taken an obligation to see that that book (constitution and by-laws) was fully lived up to. If

1 (Question by a union member):-“" Do I understand you that any question could be taken up by joint commission? Would you take our constitution and by-laws and pick flaws?"

(Answer by secretary):- "Your constitution and by-laws are not a trade question, they are not a subject for arbitration, not a subject for mutual government, and neither is ours. If you put in your constitution and by-laws that the employers must stand on their heads fifteen minutes every morning and attempt to enforce it, that question would be settled immediately by joint action. ... You can put what you please in black marks on white paper-so can we-but you have absolutely no moral right or trade right to put a line in that that governs employers. Your jurisdiction ends at that door (indicating door of convention hall).

"Our jurisdiction ends at our door. When we get out into the passageway, which is the trade, we will settle differences there jointly.... You bring that book (indicating constitution and by-laws) out there and say that governs the passage-way of the trade, we say "No," nor more than the constitution and by-laws of the church governs the trade. When you attempt to enforce it there, that is when we need mutual government.... We give you half the right and demand the other half. That is mutual government."-Proccedings of L. I. P. and B. A. Coni'ention, Igor, pp. 147-8. 
they make a law here now saying on and after, say April I 5 th, wages of pressmen shall be $\$ 50.00$ a week, if I was general president of the association, I would have to see it is so lived up to. They could not work for less than $\$ 50.00 .^{1}$

The above statement is historically true as a description of the methods formerly employed by the unions in the industry; but it is more. It is a statement of the means by which the union expected to determine the working conditions of its members, especially the 48 hour week, in Igo6. In reporting to the convention on the interview with the employers' association secretary, the spokesman for the union committee said:

I believe that our general officers don't understand what mutual government is. I believe they were taken in on that question of mutual government. . . . While you have the right under the present conditions to turn this matter over to the Law Committee, they may form your laws, but they cannot be effective until they are placed before a conference committee, and they must decide whether they are satisfied with the laws you have enacted here today, and not before then can they be looked upon as the laws of this association. That is mutual government. My advice would be to go ahead and ignore the whole thing. ${ }^{2}$

The more conservative delegates in the convention prevented radical action for a time at least until the feelings of the other unions in the industry concerning concerted action in case of trouble with the employers could be ascertained. On the same date, December I3, 1905, that the employers' association requested a conference with the L. I. P. and B. A., a similar request was sent to the Central Lithographic Trades Council. As in the letter to the L. I. P. and B. A., the employers' association added:

1 Procedings of L. I. P. and B. A. Convention, 1906, pp. 152-4.

2 Ibid., p. 137. 
IIe wonkt also inform you that the necessary legal steps are now being taken to change the name of the Lithographers' Association (liast) to the following: Employing lithographers National League, and we expect about January I2th, I905, or at any rate before the signing of the new agreement, that the members of the Association (I'acific) will have joined our Issociation and that the Employing I ithographers' National league will not only cover, but actually include in its memhership, the employing lithographers of the Last and Pacific and perhaps of other parts of the country.

Not knowing how strong this reorganized association might be and not wishing to be forced to a test of strength until the proposed action of the L. I. P. and B. A. was knwm, the Central Lithugraphic Trades Council played for time, meanwhile answering the communication of the employers and enquiring membership, functirms, etc., of the proposed league. When the L. I. P. and B. A. convention met. representatives of the Central Lithographic Trades Council appeared and outlined the following form of amalgamation of the lithographic unions:

One organization to be formed of the present craft unions. Each of the present unions to remain intact for the consideration of affairs peculiar to its special branch; the principle of referendum of the entire membership to govern the making of laws: laws for the internal government of each branch organization to conform with the general laws. Each of the bodies to have locals in every locality, whose meetings are to be optional. Monthly meetings of all the men in each locality to be held together. Local executive boards to be composed of one representative from each branch of the craft. A national executive board to be composed of one representative from each branch of the craft. One treasury for all the branches. Dues to be equal for all, regardless of branch; assessments to be either equal or percentage. For the amalgamation of the present bodies, in order to provide that each 
pay the same proportionate amount into the general treasury, each organization to contribute a per capita sum equal to that of the richest. General articles, non-amendable, guaranteeing to each branch its autonomy, and establishing the general idea of organization hereinbefore set forth, to be agreed to by each organization before the unity is established. ${ }^{1}$

The L. I. P. and B. A. was opposed to any alliance or any plan of amalgamation other than that by which the other unions should become a part of the L. I. P. and B. A.; and even this privilege was to be denied the Press Feeders' Union. Hence the above proposal was not given serious consideration in the convention. But when the employers refused to meet the L. I. P. and B. A. in convention, the latter saw the need of a defensive alliance with the other unions in case trouble should result. Representatives of the various trades, members of the Central Lithographic Trades Council, were requested to come to the convention at once. In the meantime, the constitution of the L. I. P. and B. A. was amended by striking out of article I., section 2, the last clause which provided:

But under no consideration shall the last part of this section be construed as to the formation of an alliance or affiliation. ${ }^{2}$

On February 6 to 8, I906, the alliance representatives met the committee of the L. I. P. and B. A. and discussed two propositions: First, to include the L. I. P. and B. A. in the existing alliance for defensive purposes in carrying all unions over the period of making the agreement for the ensuing year; and second, to lay the foundation for future amalgamation on the plan advocated by the L. I. P. and B. A.- that is, that the members of the other unions join

1 Proceedings of L. I. P. and B. A. Convention, 1906, p. Io9.

2Ibid., p. 168. 
this minon and be governed ly its laws. The representatives of the 1. 1. 1'. and B. 1 . were interested in the defensive alliance only as a temporary measure to prevent their emplovers from using the other minons as a whip to force an agreement from the L. I. P'. and B. A. which would not srant the fis hour week. They were more interested in linying the foundation for future amalgamation which would give them complete control over all labor in the industry.

The alliance representatives not only would not commit thenselves on the question of future amalgamation or the form of agreement to be asked for, but they insisted that in case the L. I. P. and B. $\$. applied for admittance, such application must be accompanied by a statement of demands which the L. I. P. and P. A. expected to make of the employers. In accordance with this understanding, the agreement committee of the L. I. P. and B. A. made the following recommendation to the convention:

That application be made to the proper officials of the Alliance, to become a party thereof, bringing to their notice the nature of our demand with reference to the 48 hour week, during the agreement period, the ultimate object being a view of amalgamation or closer relationship that will meet the present concentrated power of the employers. . . . .

And we further recommend that we set the date September Ist of this year for the 48 hour week. ${ }^{1}$

During the course of the discussion of these recommendations, a demand was made for the formulation of the Buffalo Convention Agreement or ultimatum previously voted upon by the convention. Accordingly, a form of contract to be presented to the employers by the L. I. P. and B. A. as an ultimatum was drawn up, embodying closed shop, minimum wage, arbitration of questions " not specifically covered by

${ }^{1}$ Proceedings of L. I. P. and B. A. Convention, 1906, pp. 216-17. 
the terms of this agreement," overtime, apprenticeship, limitation upon output, and the 48 hour week. This proposed agreement was acted upon section by section. ${ }^{1}$ The section dealing with hours of labor read as follows:

It is hereby agreed that on and after April I2th, 1906, the established work week shall consist of forty-eight (48) hours, and that in no instance shall there be a reduction of the rate of wages paid to any member of the party of the second part. ${ }^{2}$

Having adopted such an agreement or ultimatum, those who favored it tried to prevent the adoption of the alliance report. At the next session of the convention the ultimatum was reconsidered and the following resolution was adopted as a substitute for the ultimatum and the previous alliance resolution :

In view of the fact that one of the chief reasons for calling this convention was the formulation of an agreement with the employers' association, and through some misunderstanding this convention is unable to meet the employers' association, therefore I present the following:

That this association join the Alliance, and should the employers desire an agreement, that it is formulated through our representatives in said Alliance and submitted to referendum according to our laws. ${ }^{3}$

This substitute was carried by a vote of 50 to one. In discussing the advantage of joining the alliance one member said:

You (the L. I. P. and B. A.) become a member and present your agreement. If it doesn't meet with the approval of the rest of the Alliance or with the employers, you hold up the entire Alliance from entering into an agreement..... By

1 Proceedings of L. I. P. and B. A. Convention, Igo6, p. 220.
${ }^{2}$ Ibid., p. 222.
s Ibid., p. 226 . 
joining the Alliance there is every possible chance of forcing vur antecment through.'

In other words. it was expected that the other unions would be forced to help the I. I. P. and B. A. to get their ti hour week.

In the same spirit the attitude on affiliation of the L. I. P. and B. A. with the American Federation of Labor, a subject of discussion but also of adverse action for several successive years, was changed when it was pointed out that " if we join the A. F. of L., when it comes to amalgamation with all the trades. we will control jurisdiction over other trades in the industry." = Under this interpretation, it was voted to make application for affiliation with the A. F. of $\mathrm{L}$.

Following the vote to apply for admission to the Central Lithographic Trades Council, the L. I. P. and B. A. convention repudiated the purpose for which it was called, namely, to secure an agreement with the employers which must contain the 48 hour clause, by amending its constitution to permit its representatives to execute, subject to ratification by the union, "an agreement in accordance with the laws governing said Council." 3

Subsequently, the L. I. P. and B. A. was admitted to membership in the Central Lithographic Trades Council. While it was generally understood that this union expected to insist upon a $4 \delta$ hour week as a condition of signing agreements in 1906, it was not generally understood by the council that the failure to receive the shorter week would involve the entire industry in a strike.

On March 20, I906, the alliance, including the L. I. P. and $\mathrm{B}$. A.. met the representatives of the newly organized

${ }^{1}$ Proceedings of L. I. P. and B. A. Convention, 1906, p. 216.

2 Ibid., p. 228.

3 Article VIII., section $\mathrm{I}$. 
Employing Lithographers' National League and drew up a tentative agreement to be submitted to the respective organizations for ratification. The employers wanted a three-year agreement drawn similar to the existing agreement. They were unwilling to grant a 48 hour week outright, but they were willing to abide by the decision of the joint board to consider the case or by arbitration if the board failed to agree. It was generally understood that the employers would favor a plan to reduce hours gradually so that in the course of a year and a half or two years the 48 hour week would be in force.

On March 27, the alliance met the representatives of the Lithographers' Association (West) and encountered similar opposition to the proposed 48 hour week. However, again a tentative agreement was drawn up for submission to the organizations interested. The two agreements were to be accepted or rejected by April 23. In the meantime the old agreements were to remain in force. Both agreements contained clauses leaving any change in hours to be settled as any other disputed point - by the joint board or by arbitration.

Both agreements were almost unanimously rejected by all unions. The national officers of the unions used their efforts to defeat the agreements and had little trouble in persuading their constituents since they had planned for the 48 hour week in I906. Especially was this true of the members of the L. I. P. and B. A.

With one relatively unimportant exception which will be noted later, this marks the end of trade agreements in the lithographic industry. Efforts to effect a compromise followed the rejection of the tentative agreements by the unions, but by this time the employers were organized on a new basis and were already laying plans for a new régime in the control of their employees. 
The workmen were the lirst interested parties in the lithngraphic inchustry to learn the power of organization. Even as craft and semi-industrial muions involved in jurisdictional figlit a which occasionally resulted in underlidding each other in the shops, they were able for some years to dictate the terms of employment to their unorganized employers. Igain, as separate unions, they were able to maintain their allantage against at defensive alliance of employers' associations. Is an alliance of unions they were somewhat less sncessful, yet nut wholly unsuccessful, in their dealings with a single, strong, employers' association, organized for defensive purposes. The mions had never tried a single, strong, centralized form of organization. Up to this time they had never really had an encounter which made this necessary. Is the aggressors, they had found craft and semi-industrial unions, with only occasional defensive alliances when danger seemed to threaten them, sufficient to give them the balance of power or at least equal power in wage bargaining.

Their employers were apt pupils. Handicapped at first by lack of organization, they gradually added to their bargaining power until they reached the level of the unions. In fact, they were so apt in their study of the methods of wage bargaining that they saw possibilities in organization never sensed by their teachers. This caused the relations of the two parties to be reversed: the employers' association became the teacher, and the unions became somewhat indifferent pupils. 


\section{CHAPTER V}

\section{Preparation for Conflict}

THE agreements which began in 1904 and were renewed in 1905 expired in April, 1906. Pending further efforts to renew these agreements, the employers asked that the old agreements continue to govern labor conditions in the industry. The unions rejected this proposal and replied that they expected to work without agreements. By so doing they hoped to return to the preagreement period of governing their working conditions without giving their employers an equal voice. The year I906 was considered an opportune time to make this move because the employers were then temporarily disorganized. Before the real test of strength came, however, two important changes occurred.

In the first place, the domineering attitude of the $L$. I. P. and B. A. officials caused dissension in the Central Lithograhic Trades Council and the union alliance split into factions. The Poster Artists' Association and the Artists', Engravers' and Designers' League tried to form a sort of two-union alliance but failed. In July the L. I. P. and B. A. tried to induce the other unions to become a part of it through amalgamation. This also failed. Tentative plans were then drawn for the formation of the International Lithographic Trades Alliance of North America, an organization which was planned to bind the unions more closely together than did the Central Lithographic Trades Council, but which would protect the identity of the separate unions.

While the latter organization was being discussed, the L. I. P. and B. A., without the consent of the other 497] 
unions, served notice upon the employers on July 9, that the +5 hour week would go into effect on September I, and that the employers were expected to acquiesce in this demand and so notify the mion by July 25. It was announced to the other unions and understood by the employers that in case the deniand was not granted by July 25, a strike would be called August I, even though the 48 hour week was not planned to go into effect until September 1.

While the unions were drifting apart, the employers were coming together under a form of organization which assured continued allegiance to their association. Anticipating trouble with the unions, the newly formed Employing Lithographers' National League and the old Lithographers' Association (West) held a joint conference in Pittsburg on May 22 to 24 , and formed the National Association of Employing Lithographers. The new association was incorporated under the laws of the State of New York on May 31, 1906. The reason for the formation of this organization, as stated in the preamble to its constitution, was as follows:

The action of the unions of Lithographic Employees in refusing to ratify the agreements arrived at by the committees representing the Eastern and Western Lithographic Employers" Associations and the Executive Committee of the Allied Unions, makes necessary the adoption of a policy to guide all employers throughout the United States.

A National Association is therefore desirable, the purposes and objects of which shall be to foster the business of lithographers, to reform abuses relative thereto, and to secure freedom fron unjust or unlawful exactions, to produce uniformity and certainty in the customs and usages of the trade, to settle differences between its members, to promote a more enlarged and friendly intercourse between lithographers, to maintain amicable relations between the members and their 
employees, to prevent unjust and unreasonable discrimination against any person or persons by any combination, person or conspiracy in any manner relating to the business of the members of the Association, and in general to foster and advance the industrial progress of the lithographic trade; and we do hereby declare our adherence to the following

\section{DECLARATION OF PRINCIPLES.}

First: Prior to the commission of hostile action on the part of any union or unions toward any member of the Association, we favor the settlement of disputes with unions by reference of such questions to properly constituted boards of conference and arbitration, and should any labor union or unions approve and have ratified by its members, the form of conference and arbitration which is hereto appended, upon the offering to us of said agreement, for a term of not less than five (5) years, we bind ourselves to accept and ratify it.

Second: In the event of the commission of any hostile action on the part of any union or unions toward any member of this Association, the "open shop" shall be established with reference to such hostile union or unions, under such shop rules and practices as may be adopted by this National Association.

Membership in the association is "restricted to such persons as are engaged individually, or are members of firms or are stockholders in corporations which are engaged in the business of lithographing, and own and operate lithographic power presses. No applicant shall be admitted to membership in this corporation who, as an individual, or whose firm or corporation has any agreement with any union in the lithographic trade." $x$

1 Article I., section 1, of the constitution as adopted June 4, 1906. Amended July 3I, I906, to substitute "who employ lithographic help" for "own and operate lithographic power presses." Unless otherwise stated, the constitutional provisions referred to in all foot-notes are as originally adopted June 4, I906; and except where stated otherwise, they are still operative at the time this investigation is being made. 
Membership fees are "computed at the rate of Five Hundred Dollars for each lithographic press operated or owned by the member, or his firm or corporation." $x$ Upon becoming a member, each employer fills out the following note form for the full amount of his entrance fee : ${ }^{2}$

\$........ . I9I. .

Three months after date I promise to pay to the order of the Nation.ll Association of Employing Lithograpiens Dollars at Traders National Bank, Rochester, N. Y. Value received. No....... Due......

As signed by the member, this note is left undated. Instead, the member signs the following authorization which enables the association to collect the face value of the note at its discretion :

To the National Association of Employing LithograpiiERS :

It being understood that the undersigned, is indebted to the National Association of Employing Lithographers in the amount of $\$ \ldots . .$. , and said Association be.ng willing to accept a note representing said indebtedness, we the undersigned, maker and endorser of a note of blank date and in the amount of $\$ . . .$. , naming said Association as payee, do hereby authorize and empower any officer of said Association to insert in said note, herewith delivered, any date, at any time such Association may desire to negotiate or demand payment of said note.

\section{Dated}

1 Article XI., section I.

2 In case the member represents a corporation, other papers must be signed showing that such representative has been empowered by the corporation to join the association. 
The quarterly dues of the association, payable in advance, in 1906 and in 1915 were as follows:

$\begin{array}{lrr}\text { Size of press (Hoe sizes) } & 1906^{1} & 1915^{2} \\ \text { For each press no. 2 } & \$ 5.60 & \$ 3.54 \\ \text { For each press no. 3 } & 5.60 & 3.90 \\ \text { For each press no. 31/2 } & 5.60 & 4.20 \\ \text { For each press no. 4 } & 7.60 & 4.92 \\ \text { For each press no. 41/2 } & 7.60 & 5.64 \\ \text { For each offset press } & \ldots \ldots & 5.64 \\ \text { For each press no. 5 } & 9.00 & 600 \\ \text { For each press no. 51/2 } & 9.00 & 6.30 \\ \text { For each press no. 6 } & \ldots \ldots & 6.66 \\ \text { For each 1 color rotary } & 9.35 & 7.02 \\ \text { For each 2 color rotary } & 10.70 & 8.76 \\ \text { For each 3 color rotary } & 12.00 & 10.50 \\ \text { For each muiti.color } & 14.70 & 14.04\end{array}$

Special assessments may be levied by a two-thirds vote of the board of directors.

The voting power of each member of the association is "one vote for each lithographic press which he, or his firm or corporation operates or owns in his or its place of business." ${ }^{3}$ Except at the annual meetings, votes on questions submitted to the members are taken by mail or telegraph. ${ }^{4}$ Votes may also be given by proxy, provided that only a member of the association may hold a proxy. ${ }^{5}$

Except as general questions have come up at the annual meetings, the board of directors is the governing body of the association. Its powers are defined as follows :

The Board of Directors shall manage the property and

1 Constitution, I906, article XI., section 2 .

2 Constitution, I9I2, article XI., section 2.

3 Article V., section 5.

4 Article V., section 6 .

5 Article V., section 4 . 
aftairs of this corporation, and shall have absolute and complete power to do any and all acts in furtherance of the purposes and objects of this corporation. The entire power of this corporation, except such as is expressly reserved to the nembers by the Constitution, is vested in this Board. Such Board of Directors maty, from time to time, delegate the exereise of such powers as they see fit, to such standing or other committees, as they may by resolution designate. They shall fill any vacancy in any office, or in their own number, for the unexpired term of such office. A director chosen to fill a vacancy shall have the qualifications of the directors to whose office he succeeds. ${ }^{1}$ The directors shall likewise have the power to interpret this Constitution, and an interpretation once made shall be made a matter of record and shall remain fixed until changed at a meeting of this corporation. The Poard of Directors shall have such further powers as are specifically granted to them in other portions of this Constitution. A director unable to be present at any meeting of the Poard may be represented by any other member of his group, firm, or stockholder in his corporation, but such representative shall not be entitled to rote. ${ }^{2}$

Having joined the association, a member may withdraw only under the following conditions:

He shall give six months' notice in writing of his intention to withdraw and shall pay and satisfy all assessments and demands of this corporation against him. At the expiration of the six months, this corporation shall, by a vote of its Board of Directors, allow such withdrawal, provided there is no strike, lockout or boycott pending which directly affects the business of any member of this corporation. When such withdrawal shall have been permitted, the Board of Directors may, in their discretion, pay to such withdrawing member his membership fee, but shall be under no obligation to do so. ${ }^{3}$

${ }^{i}$ Directors are apportioned according to geographic units.
2 Article III., section 5 .
3 Article I., section 4 . 
Members relinquish to the association all rights to deal with labor in any way. Their duties in this respect are defined as follows:

Each member of this corporation shall be bound and governed by the Declaration of Principles of this corporation in all his relations with his lithographic employees or with organized labor in the lithographic trade, and shall also be required to strictly observe such additional rules and regulations as may from time to time be adopted by this corporation or the Board of Directors thereof, or any committee acting by the authority of such Board of Directors, for the government of the relations of the members of this corporation with such employees and to such organized labor.

No member shall do any act whatsoever which is likely to jeopardize the peaceful relations with his employees, nor shall he change or attempt to change such relations without previous permission of the Board of Directors.

It shall be the duty of each member of this corporation, upon receipt of any demand from organized labor in the lithographic trade or upon any disagreement between himself, his firm, or the corporation of which he is a member and the lithographic employees of himself, his firm, or his corporation, to at once report such demand or disagreement to the local executive committee of his group and to the National Secretary, and he shall accept the intervention or intercession of this corporation and shall yield to this corporation control and direction of the settlement of such demands or disagreement, and shall obey and carry out all the directions of this corporation as conveyed to him by the local executive committee or through any regularly authorized agent of this corporation.

Any member of this corporation who shall fail to so promptly report any such disagreement, demand or controversy shall forfeit all claims to assistance from this corporation in the settlement of such demand or disagreement, and may be punished after due trial in accordance with the provisions of this Constitution. ${ }^{1}$ 
Such provisions are:

A member who shall violate any provision of this Constitulion, do any act injurious to this corporation, or bring it into disrepute, or refuse or neglect to obey or comply with any resolntion, order or direction of the Board of Directors or of at conmintee, and any member who represents a firm or corporation, and who permits or suffers his firm or corporation to do, or neglect to do any of such things, may be disciplined or suspended from his rights and privileges as a member, or expelled from this corporation; and upon expulsion he shall immediately forfeit all property, claims and benefits, rights and privileges in this corporation and in its property. . . . . Any member who shall enter into any agreement in writing with any lithographic labor organization, shall by such act work his own immediate expulsion without further act on the part of this corporation or its Board of Directors. ${ }^{1}$

In case of a disagreement between a member of the association and his employees, "the Local Executive Committee shall take full charge of the controversy until otherwise directed by the Board. No settlement shall be made without the approval of the Board."

As already noted, no protection is given to members who violate the laws of the association;

but to such members as have fulfilled all the requirements as aforesaid, this corporation shall at once through its Board of Directors extend to the member or members involved the full weight and support of this corporation, including the

${ }_{1}$ Article I., section 6. This section was amended on July I, 1907, to provide for fines in cases of violation by members, in addition to the penalties named above, and for the means of trying finable offenses by courts of inquiry. The decisions of such courts are final except where fines exceed five hundred dollars; in these cases appeal may be made to the Board of Directors.

2 Article VIII., section 2. 
securing of men or employees, and through ordering other members, firms or corporations to perform work necessary to be done for such member or members, their firms or corporations. ${ }^{1}$

In addition, members are protected in the following manner :

The Board of Directors may loan to any member from the funds of this corporation an amount not exceeding the membership fees of such member, provided such fees have been paid into the treasury of the corporation in cash, and such paid into the treasury of the corporation in cash, and such a note made by himself, and if such member represents a firm or corporation, endorsed by such firm or corporation. Such note shall be made payable three months after date and its date shall not be filled in, but shall be blank. The blank in the date of said note may be filled in at any time that this corporation shall determine to collect or negotiate the said note, by either the President or the Treasurer of this corporation, or by any person authorized so to do by the Board of Directors. ... Such note shall at all times represent present legal debts from such member to this corporation, and the statute of limitations shall not be pleaded or taken advantage of by any maker or endorser of such note. ${ }^{2}$

Factionalism had disappeared. Alliances were discarded as ineffective. Even a strong organization for defensive purposes did not produce the results desired. Only an association with control sufficiently centralized as to insure the success of offensive action could meet the needs of the employers. Under the form of organization outlined above, the new National Association of Employing Lithographers assumed the offensive and

1 Article VIII., section 3.

2 Article XI., section 5 . 
started a new regime in the industry-a regime in which organized labor thas no voice.

Meantime, the unions were more or less inactive. They knew something of what was happening within the ranks of the employers; yet they did not take immediate steps to meet this new enemy. A little later, after hostilities had begun, they tried to take advantage of what they in turn had learned from their employers. But by this time the employers had again found new possibilities in organization. By the time the struggle was well started, the unions found themselves opposed, not only by an organization of their employers, but by the united power of all organized capital which was interested, clirectly or indirectly, in the outcome of the struggle for control of labor conditions in the lithographic industry. 


\section{CHAPTER VI}

\section{Open Shop Established}

To the secretaryship of the new association, the president appointed a lawyer - a man who had served as counsel for various other associations of employers hostile to unionism and who had made a reputation as a successful organizer of " open shops." The success of the association in its labor policy has been due very largely to the direction of this secretary; partly because of his skill in keeping the employers together and in breaking up the unions, and partly because of his other business connections which have materially aided the cause of the employers in this industry.

The new association pushed its campaign for members, laid its plans for outside assistance in case of trouble with the unions, and awaited developments. Upon receipt of the 48 hour demand from the L. I. P. and B. A., the president ${ }^{1}$ replied on July 20, 1906, as follows:

Our Association does not refuse the forty-eight hour week. Neither does it accept it. As an Association, it believes that this question can best be settled by a conference between committees of the two organizations with full power.

To this letter the president of the L. I. P. and B. A. replied on July $2 \mathrm{I}$, that the union would not grant such power and added, "I, for one, would not accept it."

1 All communications sent out by the association are signed by the president; but, with few exceptions, they are written by the secretary. 
The association innediately perfected its plans for declaring open shop. The letter to the members which carried the information concerning such declaration said in part:

The Board of Directors now feel that the lithographic trade is about to "shake off its shackles" and to emerge from the present struggle with conditions that ought to prevail at all times, and in which the nan who owns the shop is the man who controls it.

- Nthough prepared to open the fight against the unions, the association waited for the latter to make the first break in order to have public sentiment on its side. At a conference between the officers of the L. I. P. and B. A. and representatives of the association on August $I$, the latter again asked the former to obtain full power to negotiate a settlement of their differences and received the same reply as before. The representatives of the association then said:

We therefore now offer to arbitrate all questions and differences between us, and with that end in view we will appoint one arbitrator, you to appoint one, and the two so selected to appoint a third, both sides to be bound by the decision of the Board of Arbitration.

We will submit to that Board any question which may exist and concerning which we may differ. We believe that the justice or injustice of any stand taken by either the employer or the employee can be determined by such a Board and that it will determine the questions by basing its judgment solely upon principles of justice. We do not believe that any power which you may think you possess and which you may think is sufficient for the enforcement of any demand can ever demonstrate the fairness or justice of such demand.

Partly because of the bitter feeling engendered by the free indulgence in personalities at this conference, and partly because the union was unwilling to give its officers any power 
which would prevent it from securing the 48 hour week, such a proposal met expected rejection. Following this rejection, the association issued this declaration of "open shop" against the L. I. P. and B. A. :

Whereas, the L. I. P. and B. A. have committed a hostile act against this Association and its members in that said L. I. $P$. and B. A. have refused an offer to arbitrate the demand they have made for a forty-eight hour week, therefore be it

Resolved, that the National Association of Employing Lithographers adheres to its declaration of principles and favors the settlement of all disputes with unions by the reference of such questions to properly constituted boards of conference and arbitration; and it is further

Resolved, that the open shop ought to be, and with due regard for the existence and welfare of the lithographic trade must be, declared toward any union which has repudiated such a plan of amicable adjustment and has insisted upon resting the justice of its demands upon a strike and a test of strength; and it is further

Resolved, that in the departments in which the members of the L. I. P. and B. A. have been or are employed, the open shop shall hereafter exist and its principles be enforced. It is further

Resolved, that a copy of this resolution be conspicuously posted in the plants of all members of the Association, and any pressman, prover, transferrer, or other member of the $L$. I. P. and B. A., who shall report to work after such posting shall be deemed to have assented to this resolution in all its provisions.

Applicants for employment were given the following employment contract :

We herewith employ you as a ....... in our ........ Department, for a period of ......year... from above date, your work to be under the direction of the Company and sub- 
ject to the rukes and regulations of the Company, it being understood that fifty-three (53) hours are to constitute a week's work, and that overtime shall be paid for at time and one half rate, and work on Sundays and holidays is to be paid for at double time rate.

Your compensation shall be at the rate of not less than ...... for fifty-three (53) hours work.

We agree to give you permanent employment during the continuance of this agreement; we are to be under no obligation to pay you for time lost by you on legal holidays, or through sickness or vacation, which vacation shall not exceed ...... days in any one year, and shall be taken only at such time in the year as suits the business of the Company.

In case of destruction of or injury to the plant or machinery by fire, explosion, necessity for repairs, disturbance of business by strike or other cause or calamity beyond the control of the employer, the employer shall have the right to shut down its plant in whole or in part until the cause of such stoppage shall with proper diligence and dispatch be overcome, and during such time the employer will not be liable for wages or damages.

The above contract was sent out by the association as a sample, with the instructions, "Typewrite them on your letter-head." Partly as an inducement to get the better trained, reliable men to return to work, the following protection contract was offered them:

\section{NATIONAL ASSOCIATION OF EMPLOYING LITHOGRAPHERS \\ Protection Contract}

In consideration of $\ldots \ldots \ldots \ldots$ entering into and continuing in the employment of $\ldots \ldots \ldots \ldots \ldots$ or any other member of the National Association of Employing Lithographers, the Association hereby pledges and agrees for the full term of five years from the date hereof, to use its entire strength and power to protect the said employee while in the employment of any of its members, and to guarantee to him 
the right to work unmolested and peaceably side by side with other workmen, either union or non-union.

It further agrees that the wages to be paid to said employee while in the employment of any of its members shall not be less than the present minimum scale unless he is now receiving a lesser amount, in which case it shall not be lowered, and that the rate of wages for overtime and holiday work shall not be lowered.

National Association of Employing Lithographers,

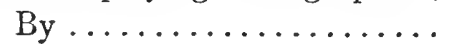

Dated August I, I906.

This paper shall not take effect until attested by the written signature of a member of the National Association of Employing Lithographers.

Attested by ..................

Member of National Association of

Employing Lithographers.

However, the association had another object in view in granting these protection agreements, for each one who signed such a paper was also asked to sign the following antistrike contract:

NATIONAI ASSOCIATION OF EMPLOYING LITIIOGRAPHERS.

$I$, the undersigned, in consideration of the signing of a protection agreement by the National Association of Employing Lithographers, which bears date of August Ist, I906, and for other considerations ${ }^{1}$ not herein attempted to be expressed, do hereby agree as part of the consideration therof:

${ }^{1}$ Such as life-insurance policies, bonuses, and other inducements offered by the employers. For example, the employers of one city gave a bonus of five dollars per week in addition to the regular wages, payable at the end of ten weeks, provided the men remained at work during that time. An additional bonus of five dollars was given to each man bringing in or assisting in bringing in a new man.-General letter no. I2. Another member of the association gave his employees a five hundred dollar life-insurance policy in return for their signature to the antistrike agreement.-General letter no. 507. 
1 shall not directly or indirectly counsel, advise, participate or aid in the declaration of any strike against the business of any present or future menber of said Association, nor in the establishment or continuance thereof, nor in any measure, financial or otherwise, designed to make it effective.

I shall in no event picket any such business nor with reference thereto carry on or participate in any system of espionage.

I shall not persuade nor attempt to persuade any of the employees of such a business to leave their employment.

Still another form of contract adopted later began as follows :

You represent to us that you are not a union man and agree not to hereafter join any union without our written consent. In consideration of this representation and the performance of the promise, we hereby employ you as a $\ldots \ldots \ldots \ldots$ for a period of ...... ycars. .... ${ }^{1}$

The object of these contracts is expressed in a letter sent out from the office of the association on August 23, I906. The letter reads in part as follows:

It would be a calamity to the lithographic trade if the strike were to break at the present time and the men were permitted to come back to work under the open shop system. If the strike were to end today there might be a repetition of the present strike next year or the year after next. We want the strike to last long enough to enable us to sign contracts with $35 \%$ of the men, and then the open shop is here and can be maintained; and another strike will be an impossibility. Make individual contracts mean a preservation of the open shop. ${ }^{2}$

Every man who returned to work was forced to resign from his union by signing a form of resignation which the

${ }^{1}$ General letter no. I04.

- General letter no. 20. Copies of all individual contracts were forwarded to the general office of the association. 
employer sent directly to the headquarters of the proper union. The resignation read as follows:

I hereby resign without any reservation from the ...., this resignation to take effect immediately.

Later a more elaborate form of resignation was used, a sample of which is as follows:

Subordinate Association No. I,

L. I. P. and B. A.,

No. 25 Third Ave., New York City.

Mr. .........., President:-

Being fully satisfied that the action of your organization in ordering the present strike against the employers is wrong, because the employers offered to arbitrate the question of the forty-eight hour week, which offer it is clearly shown you declined, and feeling that I am warranted by the action of the union which they have taken in striking against the employers as they have done, I hereby tender my resignation, to take effect inmmediately.

Respectfully yours,

This form of resignation also was furnished by the association and when signed it was mailed by the employer to the headquarters of the union.

On August 2, 1906, the L. I. P. and B. A. declared a strike against the "open shop" as thus interpreted by the employers' association. Although the other unions had advised against the attempt to secure the 48 hour week at this time, they were now placed in the position of supporting the L. I. P. and B. A. strike or being considered "scabs" by all organized labor. All but the Stone and Plate Pre-

${ }^{1}$ General letter no. 51. Dated September 22, 1906. 
parers' 'inion tried to maintain neutrality, but gradually individuals and mions became involved in the strike until only the Poster Artists' Association remained on friendly terms with the employers." Whenever a union took an active part in the strike, the association declared "open shop " against it and applied to it the same tactics as to the L. I. P. and B. 1 .

Adhering to the letter of its constitution, the association tuok full charge of the strike. No member was permitted to give to the press or to make public in any way any statement or news not authorized by the association. Occasionally a prepared statement was sent to the members with instructions to see that it reached the press.

A list of all strikers, containing such supplementary information as to make it a potential blacklist, was compiled and kept for future reference. ${ }^{2}$ Efforts were made by the association to create dissension within the unions in the hope of causing a bolt from union policies. In general letter no. 7. the association instructed its members as follows:

If you can get one or two men to break away from the union and to consent to come back under the open shop rules, it might be just as well to put him on your pay and allow him to attend the union meetings for a week or so, and, by his conversation, create a disaffection in the union. One or two men talking in that way in the union might do you a great deal more good than the same men working in your shop for a week or two. This thing has been tried with success by one of our members in the West.

In addition to the efforts of the association in trying to

${ }^{1}$ It should be kept in mind that the artists had no personal interest in this demand since they were already working less than 48 hours per week.

${ }^{2}$ General letter no. 6. 
influence public opinion directly by the control of the news which reached the press, an active campaign was waged to secure the moral and financial aid of manufacturers' and employers' associations throughout the country. Among the associations which were given credit for rendering valuable assistance were the following: National Association of Manufacturers; Citizens' Industrial Association of America; Illinois Manufacturers' Association; Commercial Association of Chicago; Employers' Association of Chicago; Merchant Tailors' National Protective Association of America; Chicago Typothetae; National Paint, Oil, and Varnish Association; Manufacturers' Association of New York; Employers' Association of Cincinnati; Citizens' Industrial Association of St. Louis; American Newspaper Publishers' Association; National Association of Cotton Manufacturers ; Employers' Association of Kansas City ; Carriage Builders' National Association; Citizens' Alliance of Seattle; Founders' and Employers' Association of Los Angeles; Association of Employing Bookbinders, New York; etc. ${ }^{1}$ There were 408 local and national associations of manufacturers and employers and 220 large corporations which received information stating the employers' side of the controversy," while it was stated that "hundreds of employers" associations are coöperating with us." 3

The aid proffered by these associations varied from direct assistance, such as legal advice and the use of detectives, to the indirect aid furnished through the distribution of pamphlets. It was claimed that the Citizens' Industrial Association of America alone sent out thousands of circular letters and pamphlets to chambers of commerce, employers'

1 General letters nos. 10, 24, 25, and 31 .

2 General letter no. 28.

${ }^{3}$ General letter no. I3. 
associations, and individuals, stating the cause of the strike and the proposed remedies for such disturbances.' Other associations served as distributing agencies for the mass of letters and other literature issued by the association and its sympathizers.

The aid furnished through the circulation of such information may be classified into three kinds: First, such circulars and pamphlets and the quotations from the same which appeared in the daily press or were given publicity in other ways influenced public opinion; second, the widespread interest in the cause of the employing lithographers. created thereby, influenced customers and kept some who otherwise would have sought satisfaction elsewhere; and third, the encouraging replies from employers of labor all over the United States inspired the members of the association to fight the strike to a finish. The association claimed that it controlled within the organization 75 per cent of the presses of the country and that an additional ten per cent was working in harmony with its labor policy. ${ }^{2}$ This is probably an overstatement. At any rate the members soon began to feel the effects of the competition of the nonassociation shops which compromised or settled with the unions and continued operations.

The encouraging replies from the employers of labor in other industries were a potent influence in keeping the members of the association true to its declaration of principles. Especially was this influence needed when many of the non-association employers in the industry granted the 48 hour week rather than face a prolonged strike. The relative numbers of employers who granted the demands of the unions and those who refused them were as follows:

${ }^{1}$ General letter no. 24.

-General letter no. 4. 
City

Number of shops granting 48 hour week

New York

Philadelphia

Providence ................... I

Springfield, Mass............... 3

Rochester ................... 6

Buffalo ...................... 3

Cleveland .................... 3

Chicago .................... 15

Milwaukee .................. 4

St. Louis .................... 7

Cincinnati $\ldots \ldots \ldots \ldots \ldots \ldots \ldots, 8$

Pittsburg ..................... 6

Denver ..................... 6

Louisville .................... 6

Baltimore ................... 8

San Francisco
Number of shops on strike

38

I

2

3

6

7

5

22

7

31

Io

o

o

5

3

o

This is an incomplete report up to August I $3 .{ }^{1}$ However, the mere number of shops is hardly a fair basis for comparison in this respect since for the most part the small shops granted the 48 hour week while the large shops refused it.

It is admitted that at the beginning of the strike the association shops were thoroughly unionized. The inducements offered by the employers and the association tempted a few members of the various unions to desert their organizations and return to work. Gradually this number increased until on September 7 , the following statement of the extent of operations was published: ${ }^{2}$

Number of shops reporting

$$
\begin{aligned}
& 66 \\
& 58 \\
& 62 \\
& 39 \\
& 60
\end{aligned}
$$

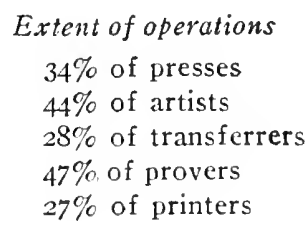

Extent of operations

$34 \%$ of presses

$44 \%$ of artists

$28 \%$ of transferrers

$47 \%$ of provers

$27 \%$ of printers

1 National Lithographer, August, 1906, p. 9.

${ }^{2}$ Undoubtedly an overstatement although strike breakers were employed wherever possible. 
This represented such a small percentage of the capacity of the industry enrolled in the association that members began to be impatient and to urge compromise with the nuions in order to get their plants in operation again and thus check the losses which they were suffering. The officers of the association were opposed to any such compromise since to take back the men without forcing their resignation from the unions, even though they should withdraw their clemands, would mean that they would retain the spirit of unionism, rebuild their unions, and make other demands at some future time. In order to prevent this, the officers of the association wished to crush unionism in the industry. once and for all. Accordingly, the board of directors of the asscciation, on September 22. I906, passed the following resolutions :

Whereas, the National Association of Employing Lithographers have declared the open shop in respect to such unions as by refusing arbitration and by striking have seriously endangered the welfare of the lithographic industry,

And whereas, for nearly eight weeks the strikers have had the opportunity to return to work and have refused to do so. and have rejected and repudiated the open shop,

And whereas, thirty-five per cent $(35)^{1}$ of the presses of the country struck August 2nd are now running under present conditions,

And whereas, the restriction of output being removed from said presses, they show a material increase in production.

It is resolved: That in order to maintain the conditions which have been established by the members of this Association, and in order to prevent the control of the industry from again drifting into union hands, no member of this National Association of Employing Lithographers shall take back, until further order by the Board of Directors, any workman who

${ }^{1}$ Probably an overstatement. 
retains his membership in the Lithographers' International Protective and Beneficial Association of the United States and Canada, the Lithographic Artists', Engravers' and Designers' League of America, the International Association of Lithographic Apprentices and Press Feeders of the United States and Canada, and the Lithographic Stone and Plate Preparers' Association of the United States and Canada. ${ }^{1}$

Five weeks later, on October 23, the total number of resignations was reported as follows: ${ }^{2}$

Members of Artists', Engravers' and Designers League .... 96

Members of L. I. P. and B. A. ................. I 35

Members of Press Feeders' Union ................ 6r

Members of Stone and Plate Preparers' Union .......... 24

Total $\ldots \ldots \ldots \ldots \ldots \ldots \ldots \ldots \ldots, \ldots \ldots \ldots, \ldots \ldots \ldots$

This represented resignations of men employed in 179 establishments which were either members of the association or were coöperating with it in its strike policy and which collectively controlled I094 presses. The number of men employed on August I in establishments controlling approximately 900 of these 1094 presses was as follows:

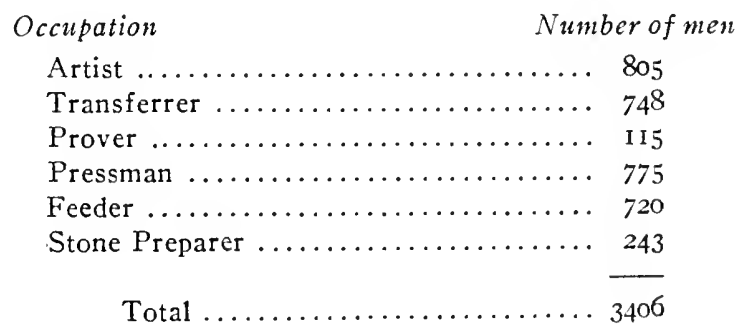

Of the total number, 1638 had been members of the L. I. P. and B. A., including the transferrers, provers, and pressmen. The others had belonged to their respective unions.

${ }^{1}$ General letter no. 51 .

${ }^{2}$ General letter no. 84. Probably an incomplete record. 
This table shoms that on the above date less than ten per cent of the strikers were reported to have returned to work. Is the strike continted. however, the reserve funds of the unions began to be exhansted. Finding it increasingly difficult to keep their members from deserting their organizations when strike benefits were discontinued for lack of funds, sume of the anion officers also began to talk compromise and to make requests for conference. Disinterested people offered their services to both parties as mediators of the strike. All such requests and offers were refused by the association. Finally the position of the employers was most emphatically smmmarized in the following statement. which was made public on November 6:

The officers and Board of Directors of the Association, and every single member of the Association are positively and finally and unaltcrably opposed to any species of conference with any of the unions on strike. . . As to us, there is no labor union in the lithographic trade in the departments in which the strike has been carried on. ${ }^{1}$

In order to get their members at work again without breaking up their organizations, some of the unions voted to let their members return to work with whomsoever they saw fit. They were even permitted to sign resignations from the unions with the understanding that such resignations would not be accepted and that they would continue their allegiance in secret. The employers detected some such cases and immediately discharged those men practicing fraud in regard to union membership. This served as a deterrent against a greater number of fraudulent resignations.

Before the strike was broken, several of the employers. members of the association, were on the verge of bankruptcy. In order to prevent them from making terms with the

${ }^{1}$ General letter no. 99. 
unions, rather than face financial ruin, the association made loans to them under article XI., section 5 of its constitution, which made ruin more sure and more immediate should they recognize the unions in any way. In a few instances members of the association did make terms with the unions in violation of their contract with the association. In one such case in which such employer's note was negotiated by the association and the proceeds confiscated, the courts were called upon to decide the legality of such regulations, passed and enforced by an employers' association.

In March, 1907, one of the large lithographic establishments in Brooklyn made an agreement with the L. I. P. and B. A. by which the hours of labor were to be fixed at 5 I per week until July I, 1907; 50 from that date until January $x, 1908$; 49 for the following six months; and 48 after July I, I908. This agreement was made by the officers of the national union and was later nullified by the New York local so that the employer never reaped any advantage. Nevertheless, the association took action to negotiate the note of the firm for $\$ 17,500$. The firm applied for an injunction to prevent the negotiation of the above note and asked that the court cause the note to be canceled on the ground that such a note was legally void and unenforceable; that the resolutions which established a closed shop against union men were in direct violation of the declared object of the association-namely, open shop; that therefore such resolutions were invalid and that the court could not enforce an unlawful rule by sustaining the forfeit of the amount of the note. The case was won by the employer in the lower courts and was carried by the association to the Appellate Division of the Supreme Court of New York. This court reversed the decision of the lower courts, by a vote of three to two, and ruled in favor of the association. ${ }^{1}$

1 See Sackett \& Williams L. \& P. Co. v. Nat. Assn. Lith., I48 A. D. N. Y. 608 for text of the decision. 
This lockent-strike probably cost the unions in actual eash expenses and in lost wages at least $\$ 1$.ooo,ooo. They lost the right to have a voice in the determination of labor conditions in the industry. Their membership declined and with it their bargaining power. Some of the aggressive leaders left the industry because its doors were forever closed against then. Since 1907 the unions against whom "open shop" was declared have regained a part of their former strength. But as yet they serve only as reminders to the employers of the necessity of maintaining their organization intact as a safeguard against possible future attacks upon their position as dictators of labor conditions in their industry.

No employer will venture an estimate of the money price lithographic capital paid for "open shop." At any rate, it seems to have been considered worth having for the association is no longer interested in "mutual government." Occasionally a member of the association thinks that the supremacy of the employers in wage bargaining in the industry is so firmly established that he favors the dissolution of the association. But the ghost of unionism keeps it intact. 


\section{CHAPTER VII}

\section{Maintenance of Open Shop}

SincE the strike the association has had no contracts with unions. It has remained on friendly terms with the Poster Artists' Association, the only union in the industry which did not strike in I906. The reasons for the continuance of friendly relations with this organization are due to circumstances peculiar to the industry and to this union.

Poster printing is a relatively small part of the lithographic industry. There are but thirty-five establishments in the United States engaged in this branch of the work; and of these only six are members of the association. Poster printing is an American industry; no other country has developed this branch of lithography. The total number of poster artists in the country does not exceed four hundred. The motion-picture business has greatly increased the demand for the products of their labor. They are a highly skilled class of men who consider themselves artists rather than artisans. In matters of unionism they adhere very closely to the provisions of their constitution.

Although they will not work with non-union men, they are opposed to trade agreements and have never attempted to establish a union wage. They realize that, regardless of unionism, the wage which a workman can command at a particular time is dependent upon the supply of such labor and the demand for it. Their statistician is always in a position to keep them informed of the demands of the trade. By a rigid limitation of the number of apprentices, the union has absolute control over the available supply of poster 
artists. It permits ane apprentice to each seven journeynen. The termofipprenticeship is four years. At the end of this time the apprentice nay be considered a journeymat, provided the minion is milling.

The employers' association has never been able to break (ip) the foster Irtists Assuciation. Since there is no organization of employing poster printers, the officers of the National Issuciation of Employing Lithographers take the initiative in calling a conference of such employers whenever it is desirable to ask concessions of this mion. For example, such a conference, held in September. I912, asked the Puster Artists Association to make the following changes in its constitution:

1. Overtime is any time other than the regular working hours of the establishment. Even though the employee may not have worked the full regular time of the week in question, except when the time lost was due to the voluntary action of the employee, it shall be paid for at the rate of time and a half. In case in any one week regular time shall be lost by the roluntary act of the employee, he shall not be entitled to time and a half for overtime until after he shall have worked the full number of regular weekly hours.

2. All apprentices shall be selected by the Shop Committee of the Poster Artists' Association of America, working in conjunction with one representative appointed by the employer. The identity of the contestant for the vacant apprenticeship need not be known to the Shop Committee or to the employer's representative.

3. There shall be an unskilled labor department in which unskilled labor shall be permitted to fill in all solids on plates; all solids in offset impressions; and to make enlargements; and such unskilled labor shall not be considered in computing the apprentice ratio.

4. The apprentice ratio shall be fixed at one (I) to six (6), or major fraction thereof, and the number of journeymen 
shall be computed by adding together the number of the journeymen employed each month during the previous calendar year and dividing by twelve (12), the number of apprentices to which each shop is entitled to remain unchanged during the calendar year. ${ }^{1}$

The Poster Artists' Association expressed a willingness to consider the first two recommendations but refused to concede the last two. Having no other recourse, since they could neither secure non-union men here nor import such men, the employers accepted this decision. To this extent there is a semblance of trade agreement in the poster printing branch of the lithographic industry.

In all other branches, the National Association of Employing Lithographers is the law-making body. Independents follow its lead in labor matters. In spite of the declaration of open shop, the association policy is still nonunion. In December, I907, the association announced to its members that open shop was assured and that they need not require of the employees resignations from their unions unless they wished; but added, "Our members may, if they choose, continue to exact resignations from their men and they may, if they choose, run strictly non-union shops. The Association will not in any way interfere with such plans." 2

Some shops are still strictly non-union, while others are practically manned by union men. In November, I909, one of the officers of the association, a man who manages one of the largest establishments in the country, boasted that "we are a closed non-union shop from top to bottom." 3

Since the strike the association has maintained its hostility to those unions against whom it declared "open shop "

1 General letter no. 748 .

${ }^{2}$ General letter no. 279.

${ }^{3}$ General letter no. 507 . 
and has not modified its constitutional regulations in regard to unimisn exept to make them more rigid. For example, in September, sgos, the board of directors adopted the following rule which is still in force:

Resolved, by the Board of Directors of the National Association of Employing Lithographers that no member of this Association shall at any time, or in any form, make use of or place upon his product the union label adopted by and belonging to any lithographic union with reference to which this Association has declared the open shop. ${ }^{2}$

Again in I9I I, when the five-year individual contracts began to expire, the association urged upon its members the necessity for renewing them "for the same reasons as those which existed when the policy was originally advocated"; namely, to prevent the unions from regaining their former strength. ${ }^{2}$

The association continually insists that all foremen at least shall be strictly non-union. Occasionally a census of all employees of its members is taken to learn how many are union men and to revise the lists kept by the association. In other ways the growth of unionism and all union activities are closely scrutinized. Means are employed to obtain information of minion activities which is not meant for the ears of employers.

The union label resolution and the reasons for its enactment have kept out of the association some employers who otherwise would like to join, but whose business depends largely upon work which requires the union label and who, therefore, cannot afford to lose such trade in becoming members of the association. At least one employer furnishes a label on work where such is required, without violating the 
terms of the above resolution. He has banded his employees into an organization which he calls the American Lithographic Union, Local No. I, and has supplied them with a suitable label which he in turn uses when occasion requires. ${ }^{1}$

In its efforts to prevent the revival of unionism, the association has adopted the policy that its members "ought, so far as possible, to bestow upon our employees all the advantages which the union could give to them in order that there may not be visited upon ourselves and our employees the disadvantages and evils of unions." As early as December I908, the board of directors submitted for discussion a proposal for a 48 hour week. ${ }^{2}$ This met with considerable opposition and the 48 hour week was not enacted until the annual meeting in I9IO. It went into effect January I, I9II. ${ }^{3}$ Even after the shorter week became effective, disgruntled employers raised objections to the association's policy. In answer to these objections, the president of the association said:

So far as the eight hours are concerned, it was in part a question of good judgment as to whether or not it was worth more to have the eight hours and no union, or to continue to have nine hours with the union growing up again and overthrowing the open shop and demanding the closed shop. In other words, it was a question of judgment as to whether or not we should make perpetual the open shop or whether we should invite, at some future date, another lithographic strike. ${ }^{*}$

Another subject much discussed as an offset to unionism is the maintenance of health and life insurance. ${ }^{5}$ The unions formerly claimed that 46 per cent of the lithographic

1 General letter no. 897.

- General letter no. 559.

${ }^{5}$ General letter no. 529, passim.
${ }^{2}$ General letter no. 415 .

${ }^{4}$ General letter no. 640. 
workmen die of tuberculosis, ${ }^{1}$ while complaints of industrial poisoning are common." Insurance has always been a strong feature of mionism in the industry. While the association has encouraged its members to insure their emphyees, it has not undertaken the insurance itself. Old-age pensions, and other kindred subjects have also been discussed from time to time.

The basis of membership in the assuciation has already been described. Except for the restrictions placed upon adnission. a constant campaign is being waged to secure new members. At present the association represents 845 presses out of approximately I 800 in the country. The membership. number of presses, and number of employees by years are as follows:

\begin{tabular}{|c|c|c|c|}
\hline Year & Number of members: & Number of presses & Number of employees \\
\hline 1907 & $\ldots \ldots \quad$ II 2 & $75 \mathrm{Ib}$ & $44^{1} 5^{c}$ \\
\hline 1908 & $\ldots \ldots$ & $\ldots d$ & $\ldots d$ \\
\hline 1909 & $\ldots \ldots$ & $\ldots d$ & $\ldots d^{d}$ \\
\hline 1910 & $\ldots \ldots$ & $732^{\mathrm{e}}$ & $4307^{c}$ \\
\hline I9II & $\ldots \ldots$ & $720 \mathrm{f}$ & $4233^{c}$ \\
\hline 1912 & $\cdots \cdots$ & $\ldots d$ & $\ldots d^{d}$ \\
\hline I9I3 & $\ldots \ldots$ & $850^{\mathrm{g}}$ & $5005^{c}$ \\
\hline I9I4 & $\ldots \ldots$ & $850^{h}$ & $5005^{1}$ \\
\hline 1915 & $\ldots \ldots \quad 12 \mathrm{I}$ & $845^{j}$ & $4868 \mathrm{c}$ \\
\hline
\end{tabular}

a All years except I9I5 as of April I ; in I9I5, January 16.

b Record for April.

c Estimate based on ratio of presses to workmen in 1914

d No record.

e Record for May.

\& Probably April.

g Record for July.

b Estimate, based on years 1913 and 1915.

i Probably about July I.

j Record for January 2.

${ }^{1}$ National Lithographer, May, 1910, p. II.

${ }^{2}$ General letter no. 687 , passim.

'General letter no. 783 , passim. 
Two employment bureaus are maintained by the association: one at New York and the other at Chicago. The duties of these employment bureaus are defined as follows:

Each bureau shall keep a full and accurate record on card indexes of every lithographic workman employed by the members of this corporation and, in so far as possible, of every lithographic workman within the jurisdiction of this corporation. The word workman as used in these rules shall be held to mean all journeymen and apprentices of the classes known as designers, poster artists, commercial artists, engravers, provers, transferrers, pressmen, feeders, stone and plate preparers, cutters and embossers. Each bureau shall daily transmit to the other bureau reports of all information and data received during the status of workmen within its juirsdiction.

It shall be the duty of each bureau to supply, as far as practicable, lithographic help to the members within its jurisdiction or to aid the other bureau in securing help for members within its jurisdiction.

It shall be the duty of the manager of each Employment Bureau to call the attention of any member violating the employment Rules to such a violation, and in case the member shall not immediately rectify the fault, then such manager shall report the same to the Committee on Employment Bureaus. ${ }^{1}$

Whenever a member engages a new employee, the name, address, rate of wages, and department of labor are sent to the employment bureau. When a workman leaves the employ of a member, the name, department of labor, rate of wages, and reasons for leaving are sent to the bureau. When the wages of the employee are increased or decreased, the name, address, former rate of wages, present rate, and department of labor are forwarded to the bureatı. In each

1 Rules governing employment bureaus: article II., section I. 
of the above cases the information is sent on the day the change is made. Whenever called upon to do so, the memlers of the assuciation forwarl to the employment bureaus complete rosters of their employees, giving names, departnient of labor. wages per week, and addresses of employees, classified into groups of foremen, journeymen, apprentices, and helpers.

In the employment of conficlential help, the following resolution, adopted by the board of directors on May 20 , 1912. governs :

Whereas, the employment by one member of the confidential office employee, superintendent, foreman, or executive head of another member, without previous notification of the intention so to employ, and the non-listing of such employee with the Employment Bureaus, frequently leads to misunderstanding; it is

Resolved, That in the judgment of this Board the members of the Association shall, previous to employing such confidential office employee, superintendent, foreman, or executive head, enquire of the Employment Bureaus whether listed or not, and if listed notify the member to be affected of the intention so to employ at a date not less than thirty days subsequent to the date of such notification. ${ }^{1}$

No aid is given to non-members of the association by the employment bureaus without the consent of the executive committee of the association. ${ }^{2}$

The activities of these bureaus in securing workmen for the members of the association are indicated in the following tables :

${ }^{1}$ Constitution and rules of the association, p. 17.

${ }^{2}$ Ibid., p. 18. By resolution adopted June $12,1908$. 


\begin{tabular}{|c|c|c|c|}
\hline \multirow[t]{2}{*}{$\left.53^{1}\right]$} & \multicolumn{2}{|c|}{ MAINTENANCE OF OPEN SHOP } & I I 5 \\
\hline & \multicolumn{2}{|c|}{ Eastern Employment Bureau } & \\
\hline $\begin{array}{l}\text { Year ending } \\
\text { April } 30\end{array}$ & $\begin{array}{l}\text { Number of } \\
\text { men listed }\end{array}$ & $\begin{array}{c}\text { Applications } \\
\text { foremployment a }\end{array}$ & $\begin{array}{l}\text { Positions } \\
\quad \text { filled }\end{array}$ \\
\hline $1906 \ldots \ldots$ & .. 880 & 8 & $\ldots \mathbf{b}$ \\
\hline $1907 \ldots \ldots$ & $\ldots 843$ & 28 & $\ldots \mathbf{b}$ \\
\hline $1908 \ldots \ldots$ & $\ldots 873$ & 36 & $\ldots \mathbf{b}$ \\
\hline $1909 \ldots \ldots$. & $\ldots 1055$ & 15 & $\ldots \mathbf{b}$ \\
\hline I9I0 ...... & $\ldots \quad \mathrm{I} 325$ & I 7I & 1262 \\
\hline I9I $1 \ldots \ldots$ & $\ldots \quad 1474$ & 190 & I I I I \\
\hline IgI $2 \ldots \ldots$ & $\ldots \quad 1476$ & 212 & $93 \mathrm{I}$ \\
\hline $1913 \ldots \ldots$ & $\ldots I 65 I$ & 271 & 915 \\
\hline $1914 \ldots \ldots$ & $\ldots \quad 1832$ & $846^{d}$ & 824 \\
\hline I9I $5 \ldots \ldots$ & $\ldots \ldots c^{c}$ & $602 e$ & $547^{\mathrm{e}}$ \\
\hline
\end{tabular}

a There is no complete record of vacancies for which men were needed.

b No record.

c See second table following.

d Including some duplications in second half of year.

e From May I, 1914, to January 23, 1915.

Western Employment Bureau

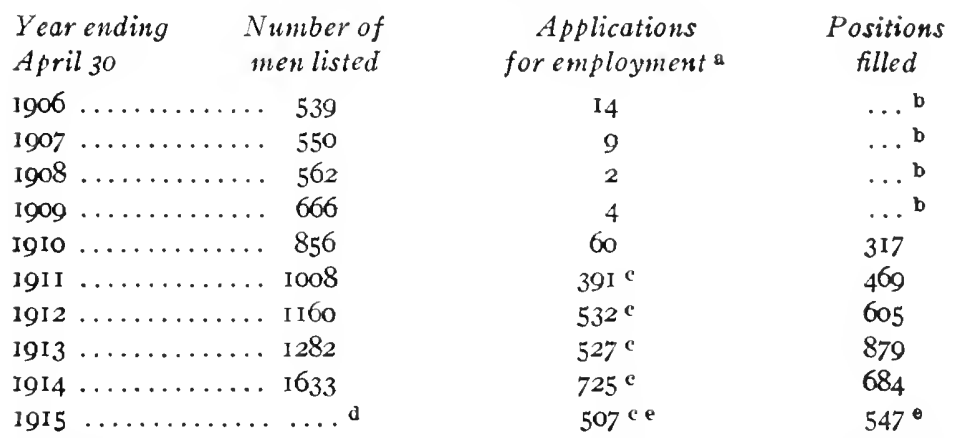

a There is no complete record of vacancies for which men were needed.

b No record.

c Includes some duplicates.

See second table following.

e From May I, 1914, to January 23, 1915.

The number of workmen listed in these bureaus at the present time is indicated in the following tables: 
Eastarn Eaployment Bureau

\begin{tabular}{|c|c|}
\hline Jowrncymen & Foremen \\
\hline Artists $\ldots \ldots \ldots \ldots \ldots \ldots \ldots \ldots \ldots \ldots \ldots$ & I5 \\
\hline Engravers ................ roo & 8 \\
\hline Designers .............. II & I \\
\hline Transferrers .............. 297 & 17 \\
\hline Provers ............... 7о & 4 \\
\hline Pressmen .............. 298 & 37 \\
\hline Feeders $\ldots \ldots \ldots \ldots \ldots \ldots 26 \mathrm{I}$ & . \\
\hline Cutters ............. $8 \mathrm{r}$ & 5 \\
\hline Stone preparers .......... 98 & I \\
\hline Embossers ............ 24 & 4 \\
\hline Helpers ................ 44 & . \\
\hline Total ............... 1595 & 92 \\
\hline \multicolumn{2}{|l|}{ Western EMPLOYMent Bureau } \\
\hline Department & Foremen \\
\hline Artists $\ldots \ldots \ldots \ldots \ldots \ldots \ldots 26_{5}$ & 26 \\
\hline Engravers ............... I46 & 16 \\
\hline Designers ............. 20 & . \\
\hline Pressmen ............. 244 & 28 \\
\hline Transferrers $\ldots \ldots \ldots \ldots \ldots .233$ & 35 \\
\hline Provers ............. 18 & $\mathbf{I}$ \\
\hline Cutters .............. 40 & I \\
\hline Joggers $\ldots \ldots \ldots \ldots \ldots \ldots \ldots$ & . \\
\hline Stone preparers .......... 66 & . \\
\hline Feeders $\ldots \ldots \ldots \ldots \ldots \ldots$ I3 8 & . \\
\hline Embossers $\ldots \ldots \ldots \ldots \ldots \ldots$ & . \\
\hline Helpers ............... I57 & $\cdots$ \\
\hline Total ............. 1336 & 107 \\
\hline
\end{tabular}

The employment bureaus are primarily places of record of all employees of members of the association. Through these records it is an easy matter to select the class of men desired by any member, discriminating against union members if the employer so desires. In spite of its open shop declarations, the association lends its aid to employers who wish to maintain non-union shop.

These bureaus also serve as a check against members who 
violate the rules of the association. For example, records of wages and the statements of wages paid to a new employee are used to enforce the association rule against hiring a man at a higher wage than he has been receiving in another shop. The record of increases and decreases of wages granted by the members of the association is as follows:

Changes in Wages since igio

\begin{tabular}{|c|c|c|c|c|c|c|c|c|}
\hline \multirow{3}{*}{$\begin{array}{c}\text { Year } \\
\text { ending } \\
\text { April } 30\end{array}$} & \multicolumn{4}{|c|}{ Eastern Bureau } & \multicolumn{4}{|c|}{ Western Bureau } \\
\hline & \multicolumn{2}{|c|}{ Increases } & \multicolumn{2}{|c|}{ Decreases } & \multicolumn{2}{|c|}{ Increases } & \multicolumn{2}{|c|}{ Decreases } \\
\hline & Jour. & $A p p$. & Jour. & $A p p$. & Jour. & $A p p$. & Jour. & $A p p$. \\
\hline I910.. & 221 & 164 & IO & $\mathbf{I}$ & 227 & 70 & 5 & 0 \\
\hline I9II & 280 & 181 & 4 & o & I 47 & 59 & 7 & 3 \\
\hline 1912 & 268 & 221 & 6 & o & I74 & 98 & 8 & I \\
\hline 1913 & 340 & 262 & 8 & 2 & 500 & 261 & I5 & 6 \\
\hline 1914 & 413 & 263 & 5 & o & $3 \mathrm{I} 4$ & I36 & 4 & 1 \\
\hline
\end{tabular}

Finally, the employment bureaus are used as agencies for the enforcement of the apprenticeship rules of the association. Rule nine of the shop rules of the association provides for the government of apprentices. This rule covers indenture, ratio of apprentices to journeymen in each branch of the industry, and penalty for violation of the rule.

By May, I9o8, the apprenticeship rules of the association had produced a marked change in the industry so that the ratio of apprentices to journeymen was as follows: ${ }^{1}$

Department

Ratio of apprentices to journeymen

Designers ................... I to $103 / 5$

Poster artists ................ I to $71 / 3$

Commercial artists ................. I to $2^{9} / 10$

Engravers ................... I to $2^{\theta} / 10$

Provers $\ldots \ldots \ldots \ldots \ldots \ldots \ldots \ldots \ldots \ldots$ I to $2 \frac{1}{1 / 5}$

Transferrers $\ldots \ldots \ldots \ldots \ldots \ldots \ldots \ldots$ I to $1 \mathrm{I} / 4$

Pressmen $\ldots \ldots \ldots \ldots \ldots \ldots \ldots \ldots \ldots$ I to $21 / 5$

Feeders ..................... I to $43 / 5$

Stone and plate preparers $\ldots \ldots \ldots \ldots \ldots$ I to $2 \mathrm{I}^{3} / 10$

Cutters ...................... I to $77^{9} / 10$

Embossers .................. I to $81 / 8$

Total ..................... I to $3 \frac{1 / 4}{4}$

1 General letter no. 354 . 
It will be seen that especially in the trades formerly controlled by the l.. I. I'. and B. A., namely the engravers. provers, transferrers, and pressmen, the ratio is mucl lower than that which obtained in 1904 . The above ratios lave been reduced since these statistics were compiled. In general the members of the association have observed the apprenticeship rules, though in some cases it has taken constant effort on the part of the officers of the association to insure the continuance of the full complement of apprentices allotted to a shop. Occasionally reminders are sent to the members concerning the employment of apprentices and the necessity for living up to the rules of the association in this respect. For example, the following general letter, quoted here in part. was sent out over the signature of the president of the association on November 7, I9I3:

The secret of Industrial Peace in any trade is a proper balance between the demand for, and the supply of, competent and skilled workmen.

Whenever the number of workmen is utterly deficient to supply the needs of any trade, with a union or without a union, wages will necessarily rise. . . Whenever the workmen of any trade are too numerous... wages will necessarily fall. ... If the shortage is excessive, wages will become unreasonably high. If the surplus is great, wages will become unjustly low.

These things are true whether there be a union or an organization of employers, or whether there be none of such things. If there be a union, the tendency of wages to rise under a situation involving a shortage of workmen will be quickened and stimulated. The existence of the union merely expedites the result.

The success of any union's efforts to be unfair or unjust depends absolutely upon a shortage of workmen. . . .

No strike ever succeeded where there were more workmen than necessary to fill the vacant positions, except perhaps 
under unusual conditions, where the general public was interested and manifested its interest.

Proper shop management and discipline depend likewise upon a proper balance between the number of positions and the number of workmen to fill the positions. . . .

To my mind, therefore, the important, and the vital work which we are doing, is the training of apprentices. The greatness of that work overshadows all else. . . .

Self preservation is the first law of nature, it is said. Rules and regulations, whether they be the rules and regulations of the union or those of an employers' association, are of little sanctity when the employer is absolutely forced to obtain a man to fill a position that it is absolutely necessary to fill, or where a workman must secure a position in order to procure the necessaries of life. All other conditions, and the obligations to any employers' association or to a union, become of secondary importance under such considerations. ${ }^{1}$

In an attempt to supplement the training of apprentices in the shops, schools for the instruction of youth wishing to enter the industry have been established, first at the Winona Technical Institute at Indianapolis, and later at the Ohio Mechanics' Institute in Cincinnati. The latter is now being given all possible encouragement by the association and it is supported by contributions from members of the association and a few outside employers.

On January 5, I9I4, what is known as the Lithographic Transferrers' Finishing School was opened at the Murray Hill School in New York City. This is conducted as a part of New York City's system of night schools. Presses, stones, plates, ink, etc. are furnished by employers or by supply houses and the Board of Education furnishes the room, heated and lighted, pays the instructor, and furnishes accessories. This is meant to be an experiment in the teach-

${ }^{1}$ General letter no. 828. 
ing of working apprentices general information about their trade which they could not obtain during the working hours under the present system of training apprentices. As such, it is considered a success.

Is indicated in the letter quoted above, the key to the labor policy of the association is the apprenticeship system. The association tries, through schools, text-books, ${ }^{1}$ and other means of education, to relicve the employer of the necessity for giving so much time to the training of apprentices in his uwn shop and during working hours. At the same time, because there has not yet been perfected any system of relieving the employer, his foremen, and his journeymen from the drudgery of training apprentices, the association insists that the employer continue to use his workshop as a school for the instruction of the future workmen in the industry.

Throughout its labor policy, the association is a stabilizing influence in the lithographic industry. Of course it is partisan, but at the same time it is managed by men who are keen students of the mechanics of wage bargaining; men who do not hesitate to pursue a policy which does not always receive the unanimous approbation of the members of the association. In this manner they sometimes bring upon themselves the criticism of some of their constituents. Yet the farsightedness which prompts the policy of the association is the influence which has saved these very members from the consequences of their own shortsightedness.

Organized as it is, the association plays aggressive labor against dictatorial capital. The former is easily dealt with tunder cxisting conditions. The fear of the blacklist is suf-

${ }^{1}$ Cf. Browne, op. cit. Mr. Browne is editor of the National Lithographer, an independent trade paper. Much of the space in this publication is given over to educational subjects. 
ficient to temper the radicalism of the trouble-making labor leader and agitator who depends upon wages at his trade for a livelihood. The ghost of unionism is used to coerce the employer into maintaining his quota of apprentices, granting concessions to his workmen, and in other ways insuring the continuance of his supremacy in wage bargaining in the lithographic industry. 


\section{CHAPTER VIII}

\section{CONClusion}

IT is not possible to measure exactly the effects of open shop upon wages and working conditions in the lithographic industry. However, both employers and workmen admit that the latter are now turning out a greater product in a unit of time than they did before open shop was established. Furthermore, in the lithographic establishments of New York City, for example, the hourly rates of wages have advanced less since open shop was established than have the rates in printing establishments where unions are still strong and where collective bargaining is still practiced.

Whether the unions can ever again obtain recognition from the employers in the lithographic industry is an open question. On the one hand, there is no evidence that the employers are willing to relinquish any of the advantages which their association has gained for them. On the other hand, the unions are taking steps to increase their bargaining power.

Since the strike socialism has been a favorite topic of discussion in the forums of the unions. Some members have joined the ranks of the Industrial Workers of the World. In general, it may be said that the members of those unions against which "open shop" was declared in 1906 are now convinced of the necessity for greater centralization of power among the wage earners in their industry. Both federation and amalgamation have been much discussed since the strike. By I9I4, this discussion had assumed the form of definite plans and the sentiment in 
favor of closer unity of action had become strong enough to force a decision as to which plan should be accepted.

The Poster Artists' Association and the Press Feeders' Union contended for an alliance similar to the one formed in 1904. This proposal was rejected by the other unions whose members voted to form an industrial union under the name of Amalgamated Lithographers of America. ${ }^{1}$ This new union claims jurisdiction over commercial artists, poster artists, engravers, designers, transferrers, provers, pressmen, press feeders, stone and plate preparers, "and such other kindred Branches of the trade as necessity and referendum may decide." 2

Both the Poster Artists' Association and the Press Feeders' Union have refused to join forces with the new organization and become part of it. In the poster printing establishments, the only workmen, other than the poster artists themselves, who are indispensable to the operation of the plant, are the pressmen, the press feeders, and the stone and plate preparers. The Press Feeders' Union can supply press feeders and even pressmen. As noted above, ${ }^{3}$ stone and plate preparers can be replaced with little difficulty. Hence as long as the Poster Artists' Association can coöperate with the Press Feeders' Union, it can insure its employers against strikes. The poster artists constitute only about five per cent of the workmen employed in the lithographic industry. Hence their lack of numbers would probably prevent them from securing, through the new industrial union, any advantages which they do not now possess, especially since their present wages and working conditions are far more satisfactory than those of the workmen in any other branch of the industry.

${ }^{1}$ The Graphic Journal (official organ of the commercial artists) November, I9I4, p. 3.

${ }^{2}$ Constitution, article II, section 2.

${ }^{3}$ Cf. p. 5, supra. 
The reasulls why the press feeders refuse to join the new union are not quite so clear. Undoubtedly the feeders have been tactlessly dealt with in the past by some of the other branches of the industry. This the new union admits and promises to correct. ${ }^{1}$ Since the press feeders are interested not only in the few poster-printing shops but also in the many commercial and black and white shops, it appears that the feeders' refusal to join the new union can result only in antagonism between the two organizations and in a consequent weakening of the bargaining power of both. In fact, the Press Feeders' Union has recently changed its name to International Lithographic Protective Association and has announced its intention of contesting the jurisdiction of the Amalgamated Lithographers of America.

The continuance of the advantages now enjoyed by the Poster Artists' Association and those members of the Press Feeders' Union who reap advantages by refusing to join the new union, will depend upon the success of the plans of the latter. As already noted, it claims jurisdiction over all branches of the lithographic industry. Its leaders have announced that it is not the

intention of the Amalgamated Association immediately after it is put into operation, to throw down the gauntlet to the organized Poster Artists and Feeders, nor is it the intention ... that the members of the new organization are to be instructed to refuse to work with non-members. It is to be hoped and expected that in the course of time both the craft organizations of Poster Artists and Feeders will recognize the necessity and desirability of becoming a part of our progressive movement, and that they will do so voluntarily and without coercion. ${ }^{2}$

${ }^{1}$ Lithographers' Journal (official organ of the Amalgamated Lithographers of America), June, 1915, p. 6.

2 The Graphic Journal, November, 19r4, p. I. 
It is quite evident however, that the new union plans to use coercion, if necessary, to force the two craft unions to become a part of it. $^{1}$

As organized at present, the above unions constitute competing rather than coöperating organizations. On the one hand, the Amalgamated Lithographers of America claim jurisdiction over the entire industry. On the other hand, the combination of Poster Artists' Association and Press Feeders' Union practically dispute the entire jurisdictional claims of the Amalgamated Association. More recently a third combination of unions has entered the jurisdictional disputes in the industry and consequently has further weakened the bargaining power of all unions, at least temporarily.

With the introduction of the offset press, the dividing line between lithography and printing became less distinct and jurisdictional disputes over the control of offset work developed. At present the International Printing Pressmen and Assistants' Union claims jurisdiction over the press work, while the International Photo-Engravers' Union claims jurisdiction over all other branches of offset printing. These two claims are supported by the allied printing trades unions.

Contrary to the policies of the unions in I904, the new industrial union of Amalgamated Lithographers of America heartily endorses the principles of trade agreements and the settlement of labor disputes by arbitration. These two subjects are much discussed within the unions and in their publications. In order to get action upon the matter if possible, the Boston local, in September, I915, sent out the following resolutions to all other locals of the national union :

Whereas, the Lithographic industry being one of the small-

1 Lithographers' Journal, passin. 
est inclustries of the Linited States and employing the smallest number of skilled workmen, there being only about 7000 in its various branclies, that fact alone should teach us that any serious labor trouble will seriously and permanently injure the lithographic inclustry; and

Whereas, the present attitude of the organized employers and organized employees is antagonistic and one of distrust, and whereas it is a true saying. "A house divided against itself shall fall," and as Lithography has to compete with other processes, and with cheap labor in Europe, it is essential for the future welfare of Lithography that the employers and the employees work in harmony, and for the present and future good of the trade; and

IThereas, government investigation has shown that over $2 / 3$ of the manufacturers of the United States are in favor of trade agreements and the settlement of all labor disputes by arbitration and the elimination of all strikes and lockouts,

Be it resolved by the Boston section, Amalgamated Lithographers of America, that strikes and lockouts are senseless and wasteful alike to both capital and labor; that such methods drive into other branches of the printers' art part of the trade so hard to obtain and retain under the most favorable conditions.

Be it resolved that we request the National Officers of the Amalgamated Lithographers of America at an early date, to ask for a conference with the Employers' Association, with the object in view of a trade agreement and arbitration of all labor differences. ${ }^{2}$

The "Boston Resolutions" have been thoroughly discussed by the other locals of the Amalgamated Association and have received the almost unanimous approval of the members of the entire national union. Whether or not the National Association of Employing Lithographers will give the request for an agreement a sympathetic hearing, and

1 National Lithographer, March, 1916, p. 38. 
whether the union will be strong enough to force an agreement from the employers in case their request is denied, are questions which future developments in the industry must settle.

With the history of the past before us, it is easy to point out mistakes made by both capital and labor in the process of wage bargaining in the lithographic industry. Given the opportunity, perhaps we think we could have avoided the consequences of these mistakes by taking another course than the one that was followed. Such speculation about what might have been is interesting at least. But more important is the bearing of this study upon the underlying principles of wage bargaining.

Unionism preceded the organization of employers in the lithographic industry. $U_{p}$ to the time the unions presented their first demands to their unorganized employers, there was in operation a system of wage determination which is sometimes called individual bargaining in contradistinction to collective bargaining. Yet before collective bargaining was tried, the hours of labor, for example, in a given labor market in the industry had been standardized and were no longer subject to individual "higgling of the market" between the employer and each of his employees.

In other words, lithography had reached the stage where labor conditions were standardized by custom. In this stage the individual workman either accepted the conditions offered him or ceased to be an applicant for the job. Whatever bargaining there was, meaning by this term the process of offer and demand and final compromise, concerned only those details of the labor contract, such as the amount of differential from the standard wage rate, which remained more or less subject to individual determination under all forms of labor contract ever tried in the industry. 
Under this system of wage determination, the labor market in the lithographic industry was more or less open. The bargaining power of both labor and capital depended upon their knowledge of the conditions of the labor market.

Labor gained advantages through organization by placing restrictions upon the choices to be exercised by capital: through closed union shop, by forcing the employer to hire union men at union terms; through apprenticeship regulations, by decreasing the supply of workmen available for a given job; through limitation upon output, by increasing the demand for workmen to produce a given product.

In 1904 even the statistics collected by the unions showed that their apprenticeship regulations were so strict that the industry could not meet the demands placed upon it except by an unusually large amount of overtime. The system practiced by the unions at that time provided both abnormally high wages and insurance against unemployment.

During the years from 1902 to 1904 the employers' appeals for justice were simply their means of expressing their selfish desire for an equalization of bargaining power. The repeated refusals of the unions to grant their employers' requests for mutual government demonstrated their superior strength when opposed only by unorganized or at least only partly organized capital.

Recognition was granted to the employers' association by the unions only when the latter began to fear the growing power of the former. Mutual government was accepted in preference to open conflict whose result could not be foreseen; the principle was rejected as soon as the unions ceased to fear the employers' organization.

The struggle which followed demonstrated the inability of the unions in the industry, unaided by the boycott and the sympathetic strike, to return victorious from a contest with a single, strong association of employers, whose weapon 
was the blacklist, and which had back of it the united strength of organized capital.

The employers, in turn, counterbalanced the advantages formerly enjoyed by the unions: by introducing the closed non-tunion shop and by dictating the terms of employment therein; by increasing the supply of labor through an enlargement of the number of apprentices; and by decreasing the demand for laborers through the removal of the restrictions upon output.

At the present time, the tables are turned and the unions are appealing for justice. Even the language which they use in expressing their faith in trade agreements and in arbitration is strikingly like that used by the employers a dozen years ago. This identity of expression is matched in the identity of the purpose of these appeals-the selfish desire for an equalization of bargaining power.

In the history of the labor contract in the lithographic industry, we have noted four stages in the method of wage determination: I. by custom; 2 . by union dictation; 3 . by mutual agreement between unions and employers; and 4 . by dictation by an employers' association. In each stage most of the terms of the labor contract were standardized; and in every stage some of its terms, especially the differentials from the standard wage rate, varied according to the different capacities of individual workmen.

In the first stage, the advantage was with the individual who best read labor market conditions; in the second, the advantage was with the union; in the third it was approximately equalized; and in the fourth, the employers have had the advantage, though the fear of the revival of unionism has prevented them from exercising it as they might otherwise have done.

In every stage of collective bargaining in the industry, the balance of power has rested temporarily with the party 
(o) manipulate the lemand for labor. in the industry in : an organization sting such power ry, is due to the union, in the face $\vdots$ the labor of its 

